\title{
Antisense Oligonucleotides, microRNAs, and Antibodies
}

\author{
Alberto Dávalos and Angeliki Chroni
}

\section{Contents}

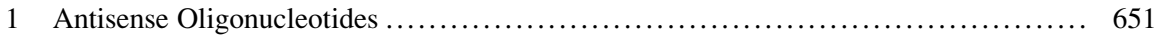

1.1 Making Sense of Antisense ....................................... 651

1.2 Therapeutic Antisense Oligonucleotides to Treat Dyslipidemia ............... 653

1.3 Therapeutic Antisense Oligonucleotides for the Increase of HDL-Cholesterol

Levels and Improvement of HDL Function ............................ 654

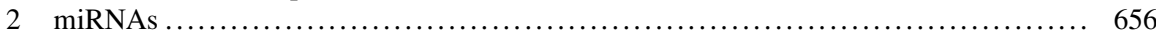

2.1 miRNA-Based Therapy .............................................. 657

2.2 Micromanaging Cholesterol Efflux, RCT, HDL Levels, and HDL Function ...... 661

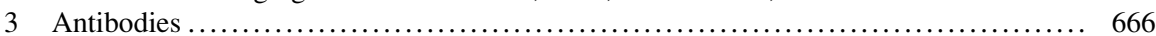

3.1 LDL-Cholesterol Lowering Approaches: Proprotein Convertase Subtilisin/Kexin Type 9 Blocking Antibodies ...................................... 666

3.2 Approaches to Antibody Therapy for the Increase of HDL-Cholesterol Levels . . . 669

3.3 Effect of Antibodies Used for the Treatment of Chronic Inflammatory Diseases on HDL Antiatherogenic Functions .................................. 671

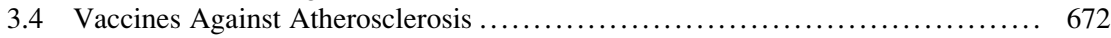

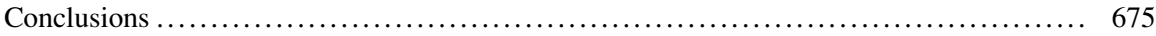

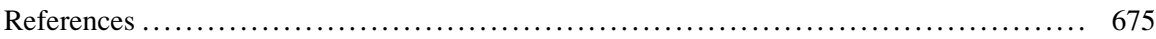

\section{Abstract}

The specificity of Watson-Crick base pairing and the development of several chemical modifications to oligonucleotides have enabled the development of novel drug classes for the treatment of different human diseases. This review

\section{A. Dávalos $(\bowtie)$}

Laboratory of Disorders of Lipid Metabolism and Molecular Nutrition, Madrid Institute for Advanced Studies (IMDEA)-Food, Ctra. de Cantoblanco 8, 28049 Madrid, Spain e-mail: alberto.davalos@imdea.org
A. Chroni $(\bowtie)$
Institute of Biosciences and Applications, National Center for Scientific Research Demokritos, Patriarchou Grigoriou and Neapoleos, Agia Paraskevi, 15310 Athens, Greece e-mail: achroni@bio.demokritos.gr 
focuses on promising results of recent preclinical or clinical studies on targeting HDL metabolism and function by antisense oligonucleotides and miRNA-based therapies. Although many hurdles regarding basic mechanism of action, delivery, specificity, and toxicity need to be overcome, promising results from recent clinical trials and recent approval of these types of therapy to treat dyslipidemia suggest that the treatment of HDL dysfunction will benefit from these unique clinical opportunities. Moreover, an overview of monoclonal antibodies (mAbs) developed for the treatment of dyslipidemia and cardiovascular disease and currently being tested in clinical studies is provided. Initial studies have shown that these compounds are generally safe and well tolerated, but ongoing large clinical studies will assess their long-term safety and efficacy.

\section{Keywords}

Antisense - Oligonucleotides - microRNAs • Antibodies - High-density lipoproteins $\bullet$ Cholesterol efflux $\bullet$ LDL-C reduction $\bullet$ HDL-C increase $\bullet$ HDL antiatherogenic function improvement $\bullet$ Atherosclerotic lesion reduction

\section{Abbreviations}

$\begin{array}{ll}\text { AAV } & \text { Adeno-associated virus } \\ \text { Ago2 } & \text { Protein Argonaute-2 } \\ \text { Apo } & \text { Apolipoprotein } \\ \text { ASOs } & \text { Antisense oligonucleotides } \\ \text { ceRNA } & \text { Competing endogenous RNA } \\ \text { CRP } & \text { C-reactive protein } \\ \text { CETP } & \text { Cholesteryl ester transfer protein } \\ \text { CHD } & \text { Coronary heart disease } \\ \text { EL } & \text { Endothelial lipase } \\ \text { EMA } & \text { European Medicines Agency } \\ \text { FDA } & \text { US Food and Drug Administration } \\ \text { HDL-C } & \text { HDL cholesterol } \\ \text { HSPs } & \text { Heat shock proteins } \\ \text { LDL-C } & \text { LDL cholesterol } \\ \text { LDLR } & \text { LDL receptor } \\ \text { LNA } & \text { Locked nucleic acid } \\ \text { miRNA } & \text { microRNA } \\ \text { mAbs } & \text { Monoclonal antibodies } \\ \text { MDA } & \text { Malondialdehyde } \\ \text { MI } & \text { Myocardial infarction } \\ \text { oxLDL } & \text { Oxidized LDL } \\ \text { PCSK9 } & \text { Proprotein convertase subtilisin/kexin type 9 } \\ \text { VEGFR2 } & \text { Vascular endothelial growth factor receptor } 2\end{array}$




\section{$1 \quad$ Antisense Oligonucleotides}

Milestone discoveries of the specificity of Watson-Crick base pairing and of RNA interference and the importance of different RNAs in the genomic regulation of living organisms have led to the emergence of different RNA-based therapeutics that hold the promise for the silencing of "drug-able" targets. Although several classes of RNA-derived therapeutics have reached clinical trials, many hurdles and challenges have reduced the number of RNA drugs that reach the market. The recent approvals of an antisense oligonucleotide (mipomersen) by FDA and a gene therapy (Glybera) by EMA, as well as several ongoing clinical trials, envision to this type of therapeutics with real future successes. Antisense oligonucleotides (ASOs), ribozymes, aptamers, miRNAs, and siRNAs are only some examples of the wide range of RNA-based therapeutics.

\subsection{Making Sense of Antisense}

The concept underlying antisense technology is simple and straightforward. Making it simple, during the first step of protein synthesis, DNA is transcribed into the complementary sequence of a messenger RNA (mRNA) molecule. The sequences of these "sense" molecules are translated into amino acids to form proteins. The use of an oligonucleotide sequence tailored complementary, by virtue of Watson-Crick base pair formation-an "antisense" strand-recognizes the specific sequence on the mRNA strand, thus preventing it from being translated into a protein and blocking the function of a gene, as it was first shown by Paul C. Zamecnik (Zamecnik and Stephenson 1978). This conceptually simple approach has given rise to a wide variety of oligonucleotide chemistries, and a new class of therapeutic compounds called antisense drugs continues to expand.

A milestone in this therapeutic arena was the FDA approval of fomivirsen (marked as Vitravene) as the first antisense oligonucleotide-based therapeutic for the treatment of a human disease in 1998, namely, for the treatment for cytomegalovirus retinitis. After numerous clinical trials of therapeutic oligonucleotides against several types of diseases (Sehgal et al. 2013), it was not until 2013 (15 years later) that the FDA approved the second antisense oligonucleotidebased therapeutic, mipomersen (marked as Kynamro), for the treatment of homozygous familial hypercholesterolemia by the inhibition of apolipoprotein B.

ASOs, both RNA and DNA molecules, are unstable in vivo due to the large amount of nucleases in plasma or cells. Moreover, problems of immune activation delivery, specificity, and other hurdles have delayed the jump from clinical trials to the market. For this, significant effort has been expanded to develop nucleaseresistant oligonucleotides with reduced immunogenicity as well as improved pharmacokinetic and pharmacodynamic properties. Many chemical modifications (Fig. 1) have been successfully developed to overcome all these hurdles.

One of the earliest chemical modification for therapeutic oligonucleotides was the phosphorothioate backbone modification (Marcus-Sekura et al. 1987; Campbell 

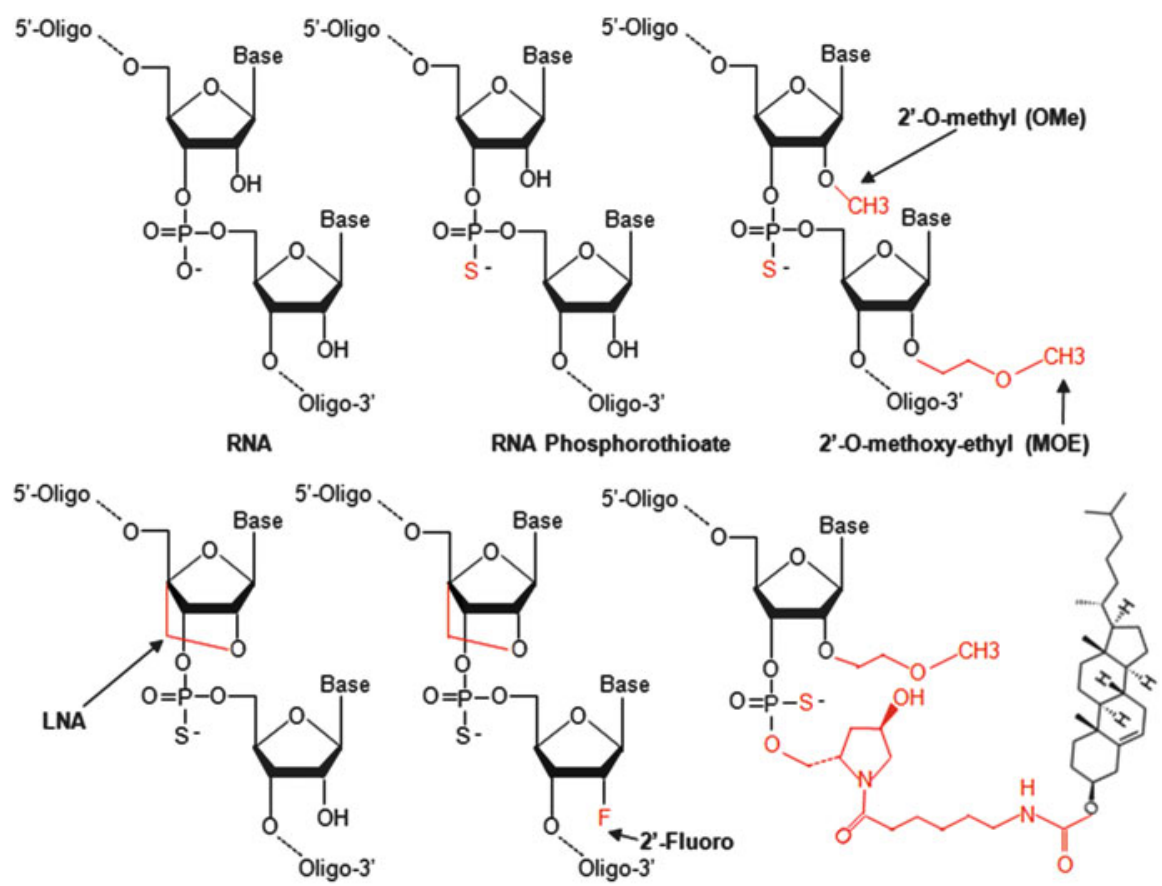

Locked nucleic acid (LNA)

2'-Fluoro (2'-F)

Cholesterol conjugation (antagomiRs)

Fig. 1 Examples of chemical modifications used in antisense oligonucleotides and miRNA therapy

et al. 1990). The replacement of the nonbridging oxygens by sulfur dramatically changed the biological properties of the oligonucleotide, making them excellent candidates for antisense application: The modified oligonucleotides display increased resistance to nucleolytic degradation, increased affinity for plasma proteins, and thus reduced clearance. They are also highly soluble and elicit RNase $\mathrm{H}$ activity which mediate the cleavage of the target mRNA (Bennett and Swayze 2010).

Sugar modification-mostly chemical substitution at the $2^{\prime}$ hydroxyl group-has conferred better drug-like properties to these molecules and have differentiated the various therapeutic strategies followed by pharmaceutical companies. $2^{\prime}-O$-methylation $\left(2^{\prime}-\mathrm{OMe}\right)$ enhances both binding affinity and nuclease resistance, but reduces off-target effects (Yoo et al. 2004; Prakash et al. 2005). 2'-fluoro (2'-F) modification also increases the binding affinity for the target driven by the electronegative substituent at this position (Monia et al. 1993; Bennett and Swayze 2010). The $2^{\prime} \mathrm{O}$-methoxyethyl (2'-MOE) modification increases binding affinity and resistance to nucleases as well (Geary et al. 2001; Yu et al. 2004). These kinds of modifications allow the oligonucleotides to adopt the most energy-favorable conformation, thus improving their pharmacological properties, and have enabled 
several MOE-modified drugs to enter clinical trials (Bennett and Swayze 2010). Another revolutionary sugar modification is the locked nucleic acids (LNA). In the LNA, the ribose moiety is modified with an extra bridge connecting the $2^{\prime}$ oxygen and $4^{\prime}$ carbon (Fig. 1) (Kumar et al. 1998). The bridge "locks" the ribose in the $3^{\prime}$-endo (Northern) conformation of sugar, which is often found in the A-form duplexes. This chemical characteristic increases hybridization, potency, and nuclease resistance but also toxicity in some cases (Swayze et al. 2007). Several LNA-modified drugs have also entered clinical trials (Sehgal et al. 2013). Several other chemical modifications to the sugar moiety have been reported in the literature; however not much of them are on clinical trials yet.

An alternative interesting strategy that improves the cellular uptake, in vivo stability, and pharmacokinetic properties is the conjugation of the oligonucleotides to different ligands, for example, to certain types of cell-permeable/penetrating peptides (Oehlke et al. 2002) or carbohydrates (Zatsepin and Oretskaya 2004). Moreover several other conjugation methods have been experimentally developed including nanostructures, liposomes, bile acid, flavin, poly(ethylene glycol), and others (Karinaga et al. 2006; Singh et al. 2010; Gonzalez-Carmona et al. 2013). However, for most of them, several challenges remain to be addressed before their preclinical and clinical development (Lee et al. 2013a, b). Cholesterol conjugation of oligonucleotides has been reported to work for multiple antisense mechanisms. Cholesterol conjugation enhances the cellular uptake, particularly hepatic, and increases in vivo stability (Holasova et al. 2005; Krutzfeldt et al. 2005, 2007). Even when it is not free of unwanted side effects, as many other antisense chemistries, cholesterol conjugation is a promising strategy to develop drug therapies.

\subsection{Therapeutic Antisense Oligonucleotides to Treat Dyslipidemia}

After less than 7 years of clinical trials (Kastelein et al. 2006; Raal et al. 2010), the first antisense oligonucleotide to treat dyslipidemia reached the market in 2013. Mipomersen sodium (marketed as Kynamro ${ }^{\mathrm{TM}}$; ISIS Pharmaceutical) is an ASO inhibitor of apolipoprotein B-100 synthesis. It is indicated as an adjunct to lipidlowering medications to reduce LDL cholesterol, apolipoprotein B (apoB), total cholesterol, and non-HDL cholesterol in patients with homozygous familial hypercholesterolemia. Other antisense therapies for the treatment of dyslipidemia are in clinical or preclinical studies, namely, the antisense drug to reduce apolipoprotein C-III (ISIS-APOCIIIRx) (Graham et al. 2013), intended to lower triglyceride production in patients with familial chylomicronemia or severe high hypertriglyceridemia, the antisense drug to reduce apolipoprotein(a) LP(a) in the liver (ISIS-APO(a)Rx) or the antisense drug to reduce angiopoietin-like 3 protein (ISIS-ANGPTL3Rx). An ASO against the hepatic microsomal triglyceride transfer protein (MTP) has also been evaluated, but even when it consistently reduced the hepatic VLDL/triglyceride secretion, it led to hepatic triglyceride 
accumulation and biomarkers of hepatotoxicity relative to apoB ASO, due in part to enhanced expression of peroxisome proliferator activated receptor $\gamma$ target genes and the inability to reduce hepatic fatty acid synthesis (Lee et al. 2013a).

Thanks to genetic studies, mutations in the proprotein convertase subtilisin/ kexin type 9 (PCSK9) were originally found to cause autosomal dominant hypercholesterolemia (Abifadel et al. 2003), which was further validated by loss-offunction mutations (Cohen et al. 2005) that lead to reduced cholesterol levels and reduced coronary heart disease (Cohen et al. 2006). PCSK9 encodes NARC-1 (neural apoptosis-regulated convertase), a human subtilase that is highly expressed in the liver and the intestine and circulates in plasma. PCSK9 binds to the LDL receptor and promotes its degradation in the endosomal/lysosomal pathway, thereby reducing LDL uptake from the circulation and increasing plasma cholesterol levels. After the premature Phase I trial termination of the PCSK9 phosphorothioate LNA RNase H antisense inhibitor SPC5001 (Santaris Pharma) and the phosphorothioate $2^{\prime}$ MOE RNase H PCSK9 antisense inhibitor (BMS-844421; BMS/ISIS), probably due to side effects (van Poelgeest et al. 2013), only ALN-PCS siRNA (Alnylam Pharmaceutical) entered Phase II clinical studies to target PCSK9 for the treatment of hypercholesterolemia. However, this strategy competes with monoclonal antibodies against PCSK9 that have already entered Phase III clinical trials (see below).

\subsection{Therapeutic Antisense Oligonucleotides for the Increase of HDL-Cholesterol Levels and Improvement of HDL Function}

HDL-cholesterol levels and function can be modified directly or indirectly by several pathways, some of which have been targeted by ASOs.

\subsubsection{Cholesteryl Ester Transfer Protein}

One of the first ASO experimentally approached to target HDL levels was directed against CETP. Sugano's lab first demonstrated that a single injection of the ASO, coupled with the complex asialoglycoprotein-poly-L-lysine, into cholesterol-fed rabbits, reduced CETP activity and increased plasma HDL-cholesterol levels (Sugano and Makino 1996). This effect was due to reduced liver CETP mRNA levels, which was accompanied by a reduction in LDL- and/or VLDL-cholesterol levels. In a longer study, 8-week treatment with the same molecule $(30 \mu \mathrm{g} / \mathrm{kg}$ twice a week) reduced both CETP mass and atherosclerosis in cholesterol-fed rabbits (Sugano et al. 1998). While triglyceride levels did not change, LDL- and VLDLcholesterol levels were significantly decreased by the ASO treatment (Sugano et al. 1998). Despite these promising preclinical antiatherogenic findings, the controversial clinical development of CETP inhibitors (Barter et al. 2007; Schaefer 2013) increased the caution for the future development of this type of therapy. In this context, recent preliminary finding suggests that inhibition of CETP by ASOs may differ from CETP inhibition by small-molecule inhibitors (Bell et al. 2013). Indeed, the 20-mer phosphorothioate ASO containing 2'-O-methoxyethyl (2'MOE) 
targeted to human CETP (ISIS Pharmaceutical) did not only reduce CETP activity and increase HDL-C levels but also enhance macrophage reverse cholesterol transport and reduce the accumulation of aortic cholesterol in a CETP transgenic $\mathrm{LDLR}^{-/-}$mice (Bell et al. 2013). This finding together with a previous study regarding the lack of association of genetic inhibition of CETP (Johannsen et al. 2012) and possible side effects previously reported for torcetrapib suggests that not all inhibitors of CETP are equal. Thus inhibition of CETP still holds promise as a beneficial therapeutic target, but as for other drugs, this needs to be experimentally and clinically validated.

\subsubsection{Endothelial Lipase}

Endothelial lipase plays an important role in HDL metabolism (Kuusi et al. 1980; Voight et al. 2012), and it has been suggested that its inhibition may improve cardioprotection (Singaraja et al. 2013). In a preliminary study, a 20-mer ASO containing $2^{\prime}-O$-(methoxy)-ethyl $\left(2^{\prime} \mathrm{MOE}\right)$ modifications on the first five and last five bases (ISIS Pharmaceutical) to target the rabbit endothelial lipase was tested in rabbits for 6 weeks (Zhang et al. 2012b). Even though the experimental protocol did not show a clear increase in HDL-cholesterol levels, the cholesterol content of large HDL ( $>12.1 \mathrm{~nm}$ ) was increased (Zhang et al. 2012b). Whether other ASO chemistries may increase the impact on HDL-C levels and function is not known, but this deserves further investigation.

\subsubsection{ACAT2}

The sterol O-acyltransferase 2 , encoded by the SOAT2 gene and originally named ACAT2 (referred here as ACAT2), is a membrane-bound enzyme, with an acylCoA cholesterol acyltransferase activity, localized in the endoplasmic reticulum. SOAT2/ACAT2 catalyzes the synthesis of cholesteryl esters from long-chain fatty acyl-CoA and cholesterol and is involved in cholesterol absorption and the secretion of cholesteryl esters into apoB-containing lipoproteins. ACAT2 is expressed exclusively in lipoprotein-producing cells, the enterocytes and hepatocytes (Anderson et al. 1998). While both hepatic and intestinal deletion of ACAT2 improves atherogenic hyperlipidemia and limits hepatic cholesteryl ester accumulation (Zhang et al. 2012a), it has been proposed that specific tissue ACAT inhibition would be beneficial for atheroprotection (Nissen et al. 2006; Brown et al. 2008). However, ACAT inhibition is not free of controversies in clinical development (Nissen et al. 2006). A 20-mer antisense phosphorothioate oligonucleotide containing 2-0-methoxyethyl groups at positions $1-5$ and $15-20$ was originally found to reduce hepatic ACAT2 levels and mediate protection against diet-induced hypercholesterolemia and aortic cholesteryl ester deposition (Bell et al. 2006). Interestingly, in mice this antisense oligonucleotide (ISIS Pharmaceutical) therapy ( $25 \mathrm{mg} / \mathrm{kg}$ biweekly for 8 weeks) promoted fecal neutral sterol excretion without altering biliary sterol secretion (Brown et al. 2008). This potentially important finding indicates that the antisense oligonucleotide promotes non-biliary fecal sterol loss and thus reverses cholesterol transport enhancement. Pharmacological inhibition of liver ACAT2 by using ASOs has also been shown to 
reduce cholesterol-associated hepatic steatosis (Alger et al. 2010) which may explain the hypertriglyceridemia observed in mice lacking ACAT2, probably by enhancing hepatic TG mobilization. In overall, ASO treatment against hepatic ACAT2 has uncovered other novel benefits distinct from that of HDL function and increased its therapeutic potential.

Although we are expecting the results of several ongoing clinical trials with ASOs for different pathologies (Sehgal et al. 2013), the recent approval for commercialization of Kynamro will really increase our interest to follow this therapeutic arena. Even when the long-term toxicity effects and other forms of delivery need to be evaluated, the promising preclinical results on ASOs to treat HDL levels and function make them an interesting alternative to small-molecule inhibitors. After all, opening new possible avenues to treat HDL dysfunction using ASOs makes more sense than simply awaiting for the discovery of potential small-molecule inhibitors.

\section{2 miRNAs}

Mature microRNAs (miRNAs) are single-stranded, 21-23 nucleotide (nt) long, and noncoding RNAs that directly bind, via Watson-Crick base pairing, to sequences commonly located within the $3^{\prime}$ untranslated region ( $3^{\prime}$-UTR) of target mRNAs. This interaction inhibits the translation and/or degradation of mRNAs (Guo et al. 2010; Krol et al. 2010). However, certain miRNAs can interact with other target mRNA regions including the $5^{\prime} \mathrm{UTR}$, coding region, or intron-exon junction and even increase rather than decrease target mRNA expression (Vasudevan et al. 2007; Orom et al. 2008; Tay et al. 2008; Schnall-Levin et al. 2010). RNA sequencing studies have identified 2,000 miRNAs in our human genome which are predicted to regulate $\sim$ a third of our genes. The binding of the "seed" sequence (nucleotides $2-8$ at the $5^{\prime}$ end of the mature miRNA) is critical for target selection (Bartel 2009). However, other regions of the miRNA can bind to the target mRNA and, therefore, almost $60 \%$ of seed interactions are noncanonical (Helwak et al. 2013). Many miRNAs are evolutionary conserved among different species. While some of them are ubiquitously expressed, certain miRNAs are highly expressed or even restricted (Lagos-Quintana et al. 2002; Small and Olson 2011) to certain cell types and can only target their mRNA target if they are co-expressed in the same tissue at the same time.

Based on short sequences ("seed"), computational methods and previous validation studies have revealed that a single miRNA can target hundreds of genes with either multiple related or different functions in different physiological/pathological processes or tissues. Likewise, a single mRNA may have different miRNA binding sites, allowing a coordinated regulation by different miRNAs. While the primary role of miRNAs seems to be the "fine-tuning" of gene expression (Flynt and Lai 2008), the appearance of this complex RNA-based regulatory network suggests that miRNAs have probably evolved as buffers against deleterious variation in geneexpression programs. Even when a single miRNA exerts modest effects on many 
target mRNAs, the additive effect of coordinated regulation of a large suite of transcripts that govern the same biological process is believed to result in strong phenotypic outputs (Mendell and Olson 2012). These basic principles of miRNA mode of function are the basis for a novel and revolutionary type of therapeutics, called the miRNA-based therapy. However, as the devil is in the details, the high redundancy among related and non-related miRNAs in the regulation of gene expression described above reduces the importance of a particular miRNA under conditions of normal cellular homeostasis. Nevertheless, since under conditions of stress, the function of miRNAs becomes especially pronounced (Mendell and Olson 2012), the modulation of miRNA function may represent a real alternative to the conventional one-target drug therapy. However, many hurdles need to be overcome as other novel players have entered the equation, including pseudo genes (Poliseno et al. 2010), long noncoding RNAs (lncRNAs) (Cesana et al. 2011), and circular RNAs (circRNAs) that contain miRNA binding sites. As competing endogenous RNAs (ceRNAs), they may sequester miRNAs and prevent them from binding to their mRNA targets (Salmena et al. 2011).

\section{1 miRNA-Based Therapy}

miRNAs as potential therapeutics have received special attention from the scientific and clinical audience primarily because of their "promiscuous" mode of action and the multifactorial nature of most modern metabolic diseases. Moreover, previous antisense technology and gene therapy approaches, some of them already in market, have catalyzed the efforts to develop therapies to modulate miRNA levels in vivo. Although certain questions regarding their biological function, regulation, and delivery still remain to be answered, the simultaneous modulation of different components of a complex disease pathway by an miRNA offers a unique and alternative opportunity to treat disease in a manner that is completely different from our conventional classical one-target-directed drugs. Eventually this feature may also enable to bypass tissue insensitivity or drug resistance, characterizing classical one-target-directed drugs.

Different pharmacological tools have been developed to target miRNA pathways (van Rooij et al. 2008, 2012; van Rooij and Olson 2012) (Fig. 2). As miRNAs are generally inhibitors of gene expression, the use of therapies to increase or block gene expression will result in a decreased or derepression of their mRNA targets, respectively. Based on these opposite approaches we can classify the therapeutic application of miRNAs into two strategies. The first strategy involves an miRNA "gain of function" phenotype, also called "inhibitors," and aims to inhibit the function of miRNAs. Several approaches can be utilized for this purpose, including (1) small-molecule inhibitors directed to regulate miRNA expression, (2) miRNA masking due to molecules complementary to the $3^{\prime}$-UTR of the target miRNA, resulting in competitive inhibition of the downstream target effects, (3) miRNA sponges that utilize oligonucleotide constructs with multiple complementary miRNA binding sites to the target miRNA, and (4) antisense 


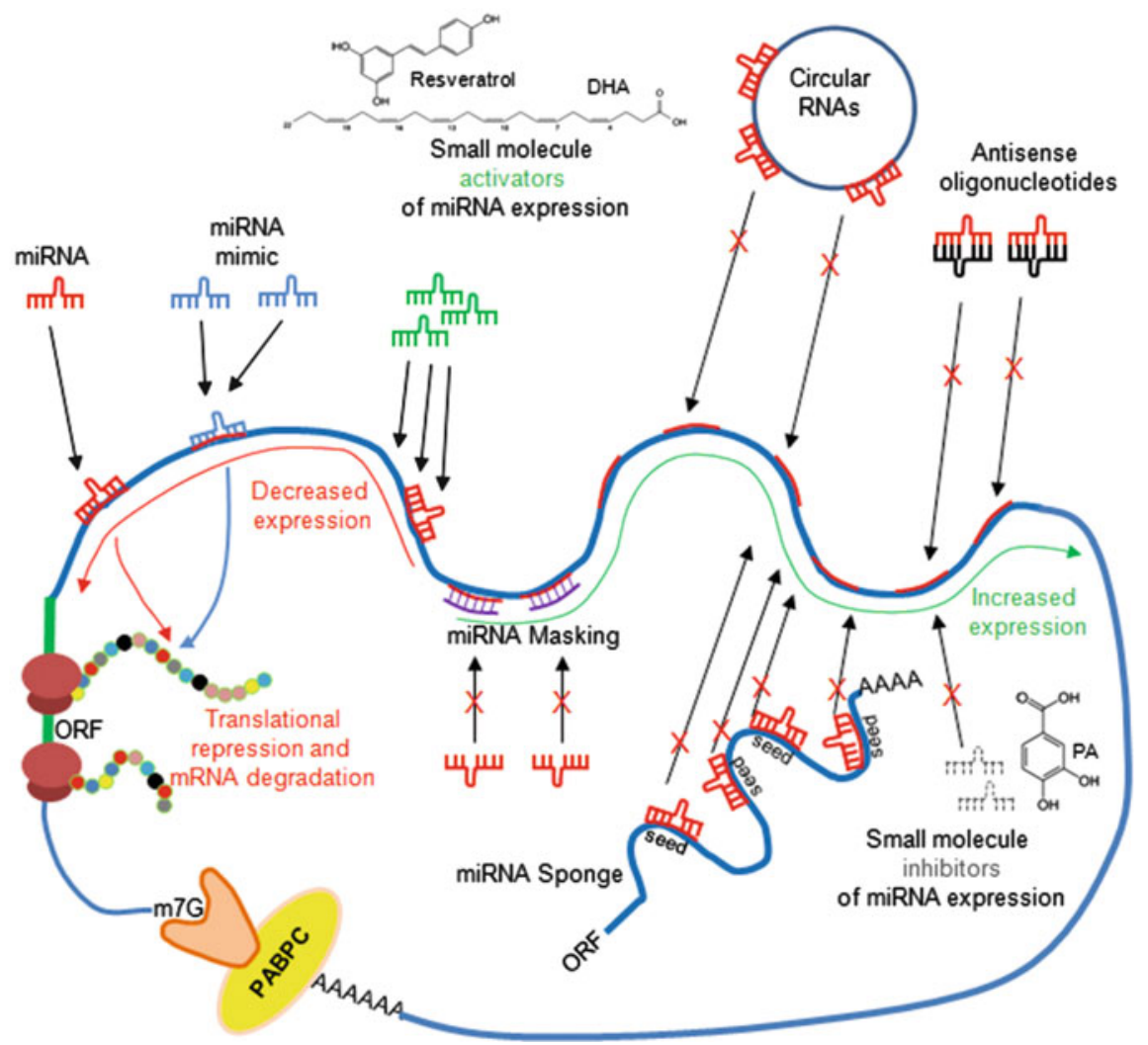

Fig. 2 miRNA-based therapy. Endogenous miRNAs bind to a complementary sequence generally localized within the $3^{\prime}$ UTR of target genes and repress the synthesis of the corresponding protein or degrade the mRNA target. For miRNA replacement therapy, an exogenous miRNA mimic is delivered systemically to exert a repression of their target genes. Small-molecule activators of miRNA expression can also be used for this purpose. For endogenous miRNA inhibition, and thus derepression of their target genes, several approaches can be used. Small-molecule inhibitors can be directed to repress an miRNA expression. miRNA masking employs molecules complementary to the $3^{\prime}$-UTR of the target miRNA, resulting in competitive inhibition of the downstream target effects. miRNA sponges use oligonucleotide constructs with multiple complementary miRNA binding sites to the target miRNA, thereby preventing them from binding to their target mRNAs. Antisense oligonucleotides, also known as miRNA antagonists, inhibitors, or anti-miRs, complementary bind to a target miRNA inducing either duplex formation or miRNA degradation. Novel approaches can arise from recent discovery of other noncoding RNAs that regulate miRNA activity. That is, circular RNAs can sequester a large amount of miRNAs acting as competitive inhibitors for miRNA binding, thereby preventing the mRNA repression of the target miRNA. $P A$ protocatechuic acid, $D H A$ docosahexaenoic acid

oligonucleotides, also known as miRNA antagonists or inhibitors, such as antimiRs, locked nucleic acids (LNA), or antagomiRs that by complementarity bind to miRNAs inducing either duplex formation or miRNA degradation (Davalos and Suarez 2013). The second strategy involves an miRNA "loss-of-function" 
phenotype, also called "mimic," and aims to enhance the function of miRNAs. The approaches that can be utilized for this strategy include (1) small-molecule activators or inductors of miRNA expression and (2) miRNA mimics, which as exogenous miRNAs aim to repress the function of their mRNA targets. They are also called "miRNA replacement therapy."

\subsubsection{Therapeutic miRNA Mimics or miRNA Replacement Therapy}

In principle, delivery of miRNA mimics as pharmacological therapy could be used in situations in which a reduction in miRNA levels is responsible for the development of a pathological state, such as those produced in the human rare Mendelian disorders or certain types of cancer, where regions containing miRNAs are deleted (Calin et al. 2002). Genetic mutation in either miRNA seed region or other miRNA regions that results in a reduced functional miRNA with a significant reduction of mRNA targeting required for normal function (Mencia et al. 2009; Ryan et al. 2010) could also benefit from these therapies. The use of miRNA mimics for therapy has been really challenging and their development has been catalyzed by gene therapy. Gene therapy was first conceptualized in 1972 (Friedmann and Roblin 1972) as an approach to deliver a gene or alter the expression of a gene in order to replace a mutated gene or deliver a therapeutic functional gene using a vector to treat a disease. Since then, the FDA has approved hundreds of clinical trials during the last 20 years using different approaches, for different diseases, with some promising results. However, it was not until 2012 that the European Medicines Agency (EMA) has approved the first gene therapy drug, alipogene tiparvovec (marked as Glybera) - for the treatment for lipoprotein lipase deficiency - and the first of its kind in the western society. It uses a viral vector, the adeno-associated virus serotype 1 (AAV1), to deliver a copy of the human lipoprotein lipase gene. As proof of concept, many preclinical data generated in animal models suggest that pharmacological delivery of miRNA mimics is feasible and current strategies to deliver miRNA mimics are promising. Indeed, a synthetic version of miR-34a (MRX34, Mirna Therapeutics), delivered using a liposomal delivery formulation, was the first miRNA to advance into a human Phase 1 clinical trial for cancer (clinicaltrials.gov number NCT01829971).

Different experimental strategies to deliver miRNA mimics have been tested. Synthetic miRNA or pre-miRNA duplexes, normally modified for better stability and cellular uptake, have been incorporated into different delivery systems, including lipid nanoparticles with surface receptor ligands or other components to increase tissue/cell specificity (Wiggins et al. 2010; Trang et al. 2011; Piao et al. 2012). Adeno-associated viruses (AAV) (Miyazaki et al. 2012) are another interesting alternative. Certain tissue specificity due to the natural tropism of different AAV serotypes (Zincarelli et al. 2008) could be achieved. Viral-based vectors, including adenoviruses and lentiviruses (Chistiakov et al. 2012; Langlois et al. 2012), consist another well-studied delivery method.

There are still questions regarding the biological function of miRNAs, particularly those related to extracellular miRNAs, intercellular communication by miRNAs, and their presence in numerous biological fluids that need to be addressed. As miRNAs can circulate in the blood or different biological fluids in 
microvesicles, exosomes, Ago2-containing complexes, or HDL (Arroyo et al. 2011; Vickers et al. 2011; Chen et al. 2012), opportunities will probably arise for therapeutically exploiting the physiologic forms of miRNA delivery (Davalos and Fernandez-Hernando 2013). The basic function of miRNAs, which is to target different mRNAs of different biological pathways, raises the possibility of unintended off-target effects (van Rooij et al. 2008). Several hurdles need to be solved including the delivery issues, as uptake of a miRNA by tissues that normally do not express them will result in the repression of their targets that could ultimately cause side effects. Moreover, the overexpression of a particular miRNA, even in its specific target cell, could modify either its own secretion or the secretion of other miRNAs that could target a different cell/tissue type causing unwanted side effects.

\subsubsection{Therapeutic miRNA Inhibition or Anti-miR Therapy}

In contrast to miRNA replacement therapy, miRNA inhibitors as therapy have benefits compared to existing antisense technology in the market. Over the last decade, several miRNAs have been characterized, and it was found that their induction or overexpression plays a causal role in a disease or directly contributes to it. Thus, pharmacological inhibition of miRNA activity in vivo has been achieved through the use of different chemically modified single-stranded reverse complement oligonucleotides known as antisense oligonucleotide (Fig. 1). Antisense oligonucleotides (ASOs) complementary to the mature miRNA sequence, "antagomiRs," were the first miRNA inhibitors in mammals (Krutzfeldt et al. 2005). Since then different chemical modifications were performed to ASOs in order to modify their pharmacological, pharmacokinetic, and pharmacodynamic properties: cholesterol, conjugated via a $2^{\prime}$-O-methyl (2'-O-Me) linkage in the $3^{\prime}$ end, to increase cellular uptake and stability; phosphorothioate linkage to increase stability and reduce clearance by promoting plasma protein binding; $2^{\prime}$-O-methyl ( $2^{\prime}$-O-methyl)-modified ribose sugar to protect from endonuclease activity (Krutzfeldt et al. 2005, 2007); 2',4'-constrained 2'-O-ethyl(cET)-modified nucleotides to improve potency and stability (Seth et al. 2010; Pallan et al. 2012); $2^{\prime}$-O-methoxyethyl (2'-MOE) and $2^{\prime}$-fluoro ( $2^{\prime}$-F) modifications to improve in vivo efficacy (Davis et al. 2009); and the $2^{\prime}$-fluoro/methoxyethyl (2'-F/MOE) modified with phosphorothioate backbone-modified anti-miR technology which has been shown to be efficacious in nonhuman primates (Rayner et al. 2011a). Lastly, locked nucleic acid (LNA) gives promising properties in order to be used as miRNA therapy. As LNA anti-miR has high-binding affinity and increased selectivity to complementary RNA, the sequence length can be reduced. LNA also increases the duplex's melting temperature and stability in biological systems (Vester and Wengel 2004; Elmen et al. 2005; Veedu and Wengel 2010). In preclinical studies LNA-modified anti-miR technology has been widely shown to be efficacious in nonhuman primates (Elmen et al. 2008; Lanford et al. 2010). Moreover, it was the first anti-miR therapy to show efficacy in human trials (clinicaltrials.gov number NCT01200420) (Janssen et al. 2013). A phosphorothioate backbone tiny 8-mer LNA-modified anti-miRs for in vivo use (Obad et al. 2011) has also been developed particularly for reducing the activity of entire miRNA families that share a common seed region. 
For now, anti-miR therapy is administered parenterally. Although miRNA inhibitors are generally water soluble, their size and charge prevent them to be absorbed by the intestine, thus becoming bad candidates for oral therapy. Their long-lasting effects shown in different studies (Krutzfeldt et al. 2005; Elmen et al. 2008; Lanford et al. 2010; Obad et al. 2011; Rayner et al. 2011a, b; van Rooij and Olson 2012) suggest their potential use for chronic rather than acute disease. Whereas under normal unstressed conditions miRNAs only slightly change protein expression (Selbach et al. 2008), pharmacological inhibition under pathological stress conditions may become relevant (Mendell and Olson 2012). Even when specific toxicity associated with the inhibition of a particular miRNA has not been clearly reported, as for other LNA-containing ASO therapies, they might not be free of potential off-target effects (Swayze et al. 2007). Thus, their evaluation might be challenging and should be done in long-lasting studies. Moreover, other miRNAs and mRNAs (independent of miRNA mediated) modified by the stress conditions and other regulatory mechanism exerted by ceRNA, IncRNAs, and circRNAs will greatly influence the pharmacodynamics of every particular antimiR chemistry.

Although there are many aspects of anti-miR biology that need to be addressed, this therapeutic approach successfully led up to the first miRNA-based clinical trials for the treatment of hepatitis $C$ virus infection by targeting miR-122 with an LNA-anti-miR (miravirsen or SPC3649; Santaris Pharma, Denmark) with very promising results (Janssen et al. 2013). Thus, the biological interest in controlling miRNAs level therapeutically anticipates the further development of this new class of drugs.

\subsection{Micromanaging Cholesterol Efflux, RCT, HDL Levels, and HDL Function}

Several miRNAs have been investigated for their potential use as therapeutics for different aspects of HDL function. Although still in preclinical studies, the pharmacological inhibition of the miRNA-33a/b is leading this aspect of research. These and other miRNAs directly or indirectly related to cellular cholesterol efflux, RCT, and HDL function that could potentially be used as pharmacological therapy will be discussed below.

\subsection{1 $\mathrm{miR}-33 \mathrm{a} / \mathrm{b}$}

The genomic localization of this family of miRNAs within the introns of the master regulators of lipid and cholesterol metabolism, the SREBPs-, has catalyzed the discovery of this miRNA as major player in HDL function and cholesterol efflux (Horton et al. 2002; Horie et al. 2010; Marquart et al. 2010; Najafi-Shoushtari et al. 2010; Rayner et al. 2010). Modulation of miR-33a/b levels in preclinical studies resulted in changes in cellular cholesterol efflux (Najafi-Shoushtari et al. 2010; Rayner et al. 2010; Davalos et al. 2011). In vivo modulation of $\mathrm{miR}-33 \mathrm{a} / \mathrm{b}$ either by target disruption of the gene, LNA anti-miR, or viral delivery 
of sense and antisense oligonucleotides significantly alters circulating HDL-C and reverse cholesterol transport (Horie et al. 2010; Marquart et al. 2010; NajafiShoushtari et al. 2010; Rayner et al. 2010), which is consistent with the regulation of its targets ABCA1, ABCG1, and NPC1. miR-33 deficiency reduces the progression of atherosclerotic plaque (Horie et al. 2012). Likewise the antisense inhibition of this miRNA for 4 weeks in $\mathrm{LDLR}^{-1-}$ mice led to the regression of atherosclerosis by enhancing $A b c a l$ expression and cholesterol removal in plaque macrophages, reducing the size and inflammatory gene expression of plaques, and increasing markers of plaque stability (Rayner et al. 2011b). Even when there is conflicting results in this aspect (Marquart et al. 2013), there is still therapeutic potential in inhibiting this miRNA family for atherosclerotic cardiovascular disease. The dramatic increase of SREBP1c (host of miR-33b) - in insulin resistance states-which contributes to both increased levels of plasma triglycerides and low HDL levels (Brown et al. 2010) also suggests the therapeutic use of anti-miR-33 for metabolic syndrome. Indeed, as proof of concept, in African green monkeys fed with a high carbohydrate diet, the inhibition of miR-33b for 12 weeks reduced hepatic expression of Abcal, increased the function of HDL evaluated as macrophage cholesterol efflux, raised plasma HDL levels, and reduced VLDL triglyceride levels (Rayner et al. 2011a).

Thus, the therapeutic potential of anti-miR-33 is not only based on Abcal, cholesterol efflux, and RCT, but miR-33a/b also controls the expression of important genes involved in fatty acid $\beta$-oxidation, insulin signaling, lipid metabolism, and biliary transporters (Allen et al. 2012; Horie et al. 2013) (Gerin et al. 2010; Davalos et al. 2011; Rayner et al. 2011a, b), including carnitine palmitoyltransferase 1A (Cptla), the carnitine O-octanoyltransferase (Crot), the mitochondrial beta hydroxyacyl-CoA dehydrogenase/3-ketoacyl-CoA thiolase/enoyl-CoA hydratase (Hadhb), sirtuin 6 (Sirt6), 5'-AMP-activated protein kinase catalytic subunit alpha-1 (PRKAA1 gene, Ampko), insulin receptor substrate 2 (Irs2), SREBP-1, and the biliary transporters ABCB11 and ATP8B1. Although specific toxicity associated to miR-33 inhibition has not been reported, its safety should be carefully evaluated as other targets related to cell proliferation, cell cycle, and inflammation, including cyclin-dependent kinase 6 (Cdk6), cyclin D1 (Ccndl), the tumor suppressor $\mathrm{p} 53$, and the nuclear receptor coregulator receptor interacting protein 140 (Rip140) have also been described (Herrera-Merchan et al. 2010; Ho et al. 2011; Cirera-Salinas et al. 2012).

Different anti-miR chemistries were tested for inhibiting miR-33 family members including LNA-antisense oligonucleotide (Najafi-Shoushtari et al. 2010) and $2^{\prime}$ F/MOE-modified phosphorothioate backbone-modified ASO (Rayner et al. 2011a, b) (Regulus Therapeutics). Interestingly, the miR-33 family has special structural characteristics, not common in most mammalian miRNAs. They have a repetitive sequence similar to that of seed (UGCAUUG) between nucleotides 13 and 19 apart from their native seed sequence between nucleotides 2 and 8 at the $5^{\prime}$ end of the mature miRNA. This could be benefited by the use of phosphorothioate backbone tiny 8-mer LNA-modified anti-miRs chemistry. Indeed recent promising results suggest the efficacy and safety of an 8-mer LNA anti-miR against 
miR-33 family during a 108-day treatment in a nonhuman primate metabolic disease model (Rottiers et al. 2013) (Santaris Pharma). Which anti-miR chemistry will have the best pharmacologic and safety profile for human use is not known, but pharmaceutical industries (Santaris Pharma and Regulus Therapeutics) are intensively researching on this topic and anti-miRs will probably soon enter clinical trials.

\subsection{2 miR-758 and miR-106b}

Like miR-33a/b, miR-758 and miR-106b target ABCA1. The expression of miR-758 is somehow mediated by high cholesterol levels and regulates cellular cholesterol efflux by directly targeting the $3^{\prime} \mathrm{UTR}$ of Abcal. As the relative expression of miR-758 is particularly elevated in the brain (Ramirez et al. 2011), it seems that it regulates other important proteins involved in several neurological functions including SLC38A1, IGF1, NTM, XTXBP1, and EPHA1. Although our understanding of the role of miR-758 under physiological and pathological conditions needs to be enhanced first, the development of appropriate anti-miR chemistries for targeting the brain miR-758 still remains to be dealt with, including bypassing the blood-brain barrier and delivery to specific cell types. Also in neuronal cells, miR-106b was found to directly target the $3^{\prime} \mathrm{UTR}$ of Abcal as having a perfect 8-mer and several supplementary pairing sites in mammals (Bartel 2009; Kim et al. 2012). The miR-106b not only reduces cholesterol efflux to apoA-I but also increases amyloid $\beta$ (A $\beta$ ) peptide secretion and clearance (Kim et al. 2012). The production and/or aggregation of $A \beta$ peptide is believed to play a central role in the pathogenesis of Alzheimer disease (AD). While the final effect might be directly linked to miR-106b effects on Abcal rather than other target genes in neuronal cells (Kim et al. 2012), we should not discard other indirect effects as this miRNA also targets various other proteins related to cell proliferation and differentiation (Brett et al. 2011). Moreover, the amyloid precursor protein (APP) is also a target of miR-106b (Hebert et al. 2009). The final phenotype of the inhibition of the neuronal miR-106b is not known, but in the context of cholesterol efflux in the CNS, miR-106b could be an interesting target for the regulation of neuronal cholesterol excess.

\subsection{3 miR-26 and miR-144}

The nuclear liver X receptors (LXRs) control distinct aspects of cholesterol homeostasis at the transcriptional level including uptake (IDOL) or efflux (ABCA1, ABCG5, ABCG8). Induction of LXR by using agonists revealed the repression of the miR-26 and the induction of the miR-144 family. LXR activation increased the expression of Abcal and ADP-ribosylation factor-like7 (Arl7), both of which participate in apoA-I-dependent cholesterol efflux (Engel et al. 2004). The miR-26-a-1 expression is also regulated by LXR (Sun et al. 2012) and directly targets the $3^{\prime} \mathrm{UTR}$ of Abcal and Arl7. Thus the inhibition of this miRNA, in principle, should enhance cholesterol efflux and RCT as LXR activation does. By contrast, LXR activation induces the expression of miR-144 (Ramirez et al. 2013). Interestingly, miR-144 is not only activated by LXR but also by the nuclear receptor 
farnesoid X receptor (FXR) (Vickers and Rader 2013). FXR is highly expressed in the liver and the intestine. It controls the hepatic sterol and bile acid levels through transcriptional regulation of lipid-associated and bile acid genes. The miR-144 directly targets the $3^{\prime} \mathrm{UTR}$ of ABCA1, thus reducing ABCA1 protein levels and cholesterol efflux, but not ABCA1 mRNA in all models tested (de Aguiar Vallim et al. 2013; Ramirez et al. 2013; Vickers and Rader 2013). In vivo therapeutic inhibition of miR-144 by using either $2^{\prime}$-fluoro/2'-methoxyethyl, phosphorothioate backbone-modified anti-miRs (Regulus Therapeutics) $5 \mathrm{mg} / \mathrm{kg}$ biweekly treatments (intraperitoneal injections) for 4 weeks (de Aguiar Vallim et al. 2013) or mirVana inhibitors $(7 \mathrm{mg} / \mathrm{kg}$ ) coupled with In vivo fectamine (Invitrogen) for intravenous injections twice every 3 days (Ramirez et al. 2013) increased both hepatic ABCA1 protein expression and HDL-C levels in mice. It is important to note that the hepatic effect of miR-144 might differ from that of miR-33a/b (Vickers and Rader 2013). Activation of FXR will induce both the scavenger receptor B1 (SCARB1) and miR-144, thereby increasing the uptake of plasma HDL cholesterol and reducing both ABCA1 protein levels and cholesterol efflux to lipid-poor apoA-I. This would lead to increased biliary excretion of cholesterol via ABCG5/ABCG8 rather than resecretion of cholesterol via ABCA1 to pre $\beta-\mathrm{HDL}$ and the formation of HDL (de Aguiar Vallim et al. 2013). The final therapeutic outcome by modulating miR-144 levels in vivo and other questions regarding safety issues still need to be experimentally tested, as other miR-144 targets are directly related to cancer proliferation (Guo et al. 2013; Zhang et al. 2013).

\subsection{4 miR-10b, miR-128-2, miR-145}

Several other miRNAs have been described to regulate ABCA1, ABCG1, and other genes related to cholesterol efflux. In the context of small-molecule activators to either induce or repress miRNAs expression, polyphenols and fatty acids are emerging as possible candidates to exert part of their biological effects by this mechanism (Visioli et al. 2012; Tome-Carneiro et al. 2013). Anthocyanidins are pigmented polyphenols found in different vegetables, fruits, as well as common beverages including grape and berry juice and red wine. Protocatechuic acid (PCA) was found to be an intestinal microbiota metabolite of Cyanidin-3-O-glucoside (Cy-3-G), a major anthocyanidin. Interestingly the antiatherogenic effect of PCA was recently found to be mediated through miR-10b (Wang et al. 2012). Indeed, PCA increases macrophage cholesterol efflux through the repression of miR-10b. The miR-10b directly represses Abcal and Abcgl and negatively regulates cholesterol efflux from lipid-loaded macrophages (Wang et al. 2012). Although several genes involved in cancer progression are targets of the oncogenic miR-10b (Gabriely et al. 2011; Tsukerman et al. 2012), its inhibition by either anti-miR chemistries or dietary intervention with anthocyanidins may be an interesting pharmacological approach to increase cholesterol efflux and RCT. The use of other pharmacological approaches, including small natural dietary compounds, is still under intense investigation (Visioli and Davalos 2011) and provides an attractive alternative to the use of ASOs or miRNA mimic technology. 
miR-145 was described as a major regulator of smooth muscle fate by targeting a network of transcription factors, including Klf4, myocardin, and Elk-1 which regulate the quiescent versus proliferative phenotype of smooth muscle cells (Cordes et al. 2009). miR-145 also regulate ABCA1 expression and function. In pancreatic beta cells, its inhibition improves glucose-stimulated insulin secretion. Inhibition of miR-145b has been shown to increase ABCA1 expression, promoting HDL biogenesis in the liver and improving glucose-stimulated insulin secretion in islets (Kang et al. 2013). The miR-128-2 was described to be frequently downregulated in breast cancer, and its overexpression impeded several oncogenic traits of mammary carcinoma cells (Qian et al. 2012). ABCA1, ABCG1, and RXR $\alpha$ are direct targets of miR-128-2, and its inhibition induces cholesterol efflux (Adlakha et al. 2013). Although we lack in vivo evidence of their pharmacological modulation and HDL function, recent evidence of association of cholesterol levels and cancer (Nelson et al. 2013) warrants further investigation of these miRNAs.

\subsubsection{Other miRNA Related to Cholesterol Efflux and Cholesterol Homeostasis}

Several other miRNAs have been described to indirectly regulate different aspects of cholesterol efflux, RCT, and cholesterol metabolism, but their real physiological contribution to HDL function is not well understood. Several miRNAs have been described that regulate different targets in autophagy (Xu et al. 2012), the cell catabolism process by which unnecessary or dysfunctional cellular components are degraded through the lysosomal machinery. Lipid droplet cholesteryl ester hydrolysis is being recognized as an important step in cholesterol efflux (Ouimet et al. 2011); thus miRNAs that target key pathways in lipid-loaded macrophage autophagy and/or cholesterol ester hydrolases might be interesting targets to promote cholesterol efflux (Davalos and Fernandez-Hernando 2013). Caveolin, the major protein coat of caveolae, has also been proposed to contribute to cellular cholesterol efflux (Truong et al. 2010; Kuo et al. 2011). Even when there is increasing evidence of several miRNAs including miR-103, miR-107, miR-133a, miR-192, miR-802, and others that target caveolin (Nohata et al. 2011; Trajkovski et al. 2011), their contribution to cholesterol efflux and RCT remains unknown. miR-125a and miR-455 were found to repress the lipoprotein-supported steroidogenesis by targeting SR-BI (Hu et al. 2012). miR-185, miR-96, and miR-223 were also found to target SR-BI and repress HDL-cholesterol uptake (Wang et al. 2013). Even though there is lack of evidence for any effect on HDL metabolism and in vivo pharmacological modulation for any of those miRNAs, the major role of SR-BI in HDL metabolism warrants further research on this topic.

Although the potential of LNA anti-miR-122-based therapy (Miravirsen, Santaris Pharma) is fascinating, much more needs to be elucidated about miRNA biology and miRNA regulatory networks in human diseases before we can introduce such research into clinical care. Moreover, new opportunities for therapeutic interventions by exploiting the different physiologic forms of miRNA delivery in biological fluids (associated with microvesicles, exosomes, Ago2-containing complexes, or HDL particles) will arise. In addition, in the postgenomic and 
"RNA world" era, new types and new roles of noncoding RNAs continue to emerge, suggesting that there is much yet to be discovered in this therapy arena.

3 Antibodies

The use of monoclonal antibodies (mAbs) for the treatment of various diseases, including cancers and autoimmune diseases, has been established for at least 15 years. The specificity of mAbs to the target antigen offers clear benefit for their use over conventional pharmacotherapy. Today mAbs are being developed for the treatment of dyslipidemia and cardiovascular disease. An overview of approaches to antibody therapy for the decrease of LDL cholesterol, increase of HDL cholesterol, treatment of HDL dysfunction, and reduction of cardiovascular events is provided below. In addition, approaches of active immunization to modulate atherosclerosis with promising results in preclinical studies are discussed.

\subsection{LDL-Cholesterol Lowering Approaches: Proprotein Convertase Subtilisin/Kexin Type 9 Blocking Antibodies}

Statins reduce LDL-cholesterol (LDL-C) levels by increasing the hepatic uptake of LDL through inhibiting HMG CoA reductase and subsequently cholesterol biosynthesis. A meta-analysis of data from 90,056 participants in 14 randomized trials showed that statin therapy can safely reduce the 5-year incidence of major coronary events, coronary revascularization, and stroke by about one fifth per mmol/L reduction in LDL-C (Baigent et al. 2005). In addition a newer meta-analysis of data from 170,000 participants in 26 randomized trials of statins showed that each $1 \mathrm{mmol} / \mathrm{L}$ LDL-cholesterol reduction reduces the risk of occlusive vascular events by about a fifth, irrespective of baseline cholesterol concentration, which implies that a 2-3 mmol/L reduction would reduce risk by about 40-50\% (Baigent et al. 2010). However, a significant proportion of patients treated with statins fail to achieve the recommended levels of LDL-C (Catapano 2009). Furthermore, even when LDL-C is reduced at the recommended levels by statins, there is a residual 50-60\% risk, and therefore, new targets for therapeutic intervention need to be developed.

Loss-of-function mutations in proprotein convertase subtilisin/kexin type 9 (PCSK9) gene result in low levels of LDL-C and protect against coronary heart disease. These observations have made PCSK9 one of the most intensively investigated novel targets to treat hypercholesterolemia (Cohen et al. 2005, 2006). PCSK9, a protein mainly expressed in the liver and intestine, is present in human plasma (Lambert et al. 2012). PCSK9 binds to LDL receptors (LDLRs) and thereby targets the internalized receptor to lysosomal degradation and thus limits recycling of receptor to the plasma membrane for LDL uptake (Zhang et al. 2007). Statins have been shown to increase PCSK9 expression, an effect that blunts the LDL-C lowering effectiveness of statins (Mayne et al. 2008). Therefore, the 
inhibition of interaction between PCSK9 and LDLR is expected to increase the LDLRs that are available in the plasma membrane of hepatocytes and as a consequence reduce plasma LDL-C. In addition, blocking the interactions between PCSK9 and LDLR may increase the lipid-lowering efficacy of statins.

Various approaches for decreasing PCSK9 levels or blocking PCSK9/LDLR interactions are being explored. By far the most advanced approach aims to inhibit PCSK9/LDLR interactions by the use of monoclonal antibodies targeting PCSK9 (Catapano and Papadopoulos 2013; Kramer 2013). Currently, clinical or preclinical trials for at least 13 different anti-PCSK9 antibodies are being conducted, with two compounds having entered Phase 3 of clinical development (Catapano and Papadopoulos 2013; Kramer 2013) (Table 1).

Preclinical studies in rodents and nonhuman primates showed that several antiPCSK9 antibodies increased hepatic LDLR protein levels and reduced plasma LDL-C levels up to $80 \%$ (Chan et al. 2009; Gusarova et al. 2012; Liang et al. 2012; Chaparro-Riggers et al. 2012; Zhang et al. 2012c; Ni et al. 2011). Reported results from Phase 1 studies in humans using REGN727/SAR236553 (alirocumab), AMG 145 (evolocumab), and PF-04950615 (RN316, bococizumab) anti-PCSK9 antibodies showed that the treatments are generally well tolerated and significantly reduce plasma LDL-C levels in healthy subjects or hypercholesterolemic patients, both as monotherapy and when added to statin treatment (Stein et al. 2012b; Dias et al. 2012; Gumbiner et al. 2012a, b). Phase 2 trial results have also been reported for alirocumab and evolocumab anti-PCSK9 antibodies. When alirocumab was administered subcutaneously at doses ranging from 50 to $150 \mathrm{mg}$ every 2 weeks or $200-400 \mathrm{mg}$ every 4 weeks to patients with primary hypercholesterolemia on top of ongoing stable atorvastatin therapy $(10,20$, $40,80 \mathrm{mg} /$ day), additional reductions in LDL-C, than that accomplished with atorvastatin alone, were observed (McKenney et al. 2012; Roth et al. 2012). The reduction of LDL-C levels was found to be similar irrespective of statin dose, indicating that the coadministration of alirocumab with atorvastatin may provide benefit to patients that fail to achieve their LDL-C target using high-dose statins or are intolerant to high-dose statins (McKenney et al. 2012; Roth et al. 2012). Great reductions in LDL-C levels were also obtained when evolocumab was administered at doses ranging from 70 to $140 \mathrm{mg}$ every 2 weeks or $280-420 \mathrm{mg}$ every 4 weeks to patients with hypercholesterolemia, either as a monotherapy or in combination with a stable dose of statin with or without ezetimibe therapy, or to statin-intolerant patients due to muscle-related side effects on ezetimibe therapy (Giugliano et al. 2012; Koren et al. 2012; Sullivan et al. 2012). In other studies of patients with heterozygous familial hypercholesterolemia and elevated LDL-C on intensive statin use, with or without ezetimibe therapy, the administration of alirocumab or evolocumab resulted in substantial further LDL-C reduction (Stein et al. 2012a; Raal et al. 2012). In addition to their capacity to reduce LDL-C levels, alirocumab and evolocumab were shown to reduce lipoprotein $(\alpha)$ levels in patients with hypercholesterolemia receiving statin therapy (McKenney et al. 2012; Desai et al. 2013) or patients with heterozygous familial hypercholesterolemia on statins, with or without ezetimibe therapy (Stein et al. 2012a; Raal et al. 2012). 
Table 1 PCSK9 blocking antibodies in clinical and preclinical development

\begin{tabular}{|c|c|c|c|}
\hline Drug candidate & Company & $\begin{array}{l}\text { Development } \\
\text { phase }\end{array}$ & $\begin{array}{l}\text { Literature or } \\
\text { ClinicalTrials.gov } \\
\text { Identifier }\end{array}$ \\
\hline $\begin{array}{l}\text { REGN727/ } \\
\text { SAR236553 } \\
\text { (alirocumab) }\end{array}$ & $\begin{array}{l}\text { Sanofi/Regeneron } \\
\text { Pharmaceuticals }\end{array}$ & Phase 3 & $\begin{array}{l}\text { NCT01709513 } \\
\text { NCT01709500 } \\
\text { NCT01730053 } \\
\text { NCT01926782 } \\
\text { NCT01644474 } \\
\text { NCT01644188 } \\
\text { NCT01663402 } \\
\text { NCT01507831 } \\
\text { NCT01623115 } \\
\text { NCT01617655 } \\
\text { NCT01644175 } \\
\text { NCT01730040 } \\
\text { NCT01954394 }\end{array}$ \\
\hline $\begin{array}{l}\text { AMG } 145 \\
\text { (evolocumab) }\end{array}$ & Amgen & Phase 3 & $\begin{array}{l}\text { NCT01652703 } \\
\text { NCT01849497 } \\
\text { NCT01813422 } \\
\text { NCT01763918 } \\
\text { NCT01516879 } \\
\text { NCT01763866 } \\
\text { NCT01763905 } \\
\text { NCT01763827 } \\
\text { NCT01764633 } \\
\text { NCT01854918 }\end{array}$ \\
\hline $\begin{array}{l}\text { PF-04950615 } \\
\text { (RN316, } \\
\text { bococizumab) }\end{array}$ & Pfizer & Phase 2 & $\begin{array}{l}\text { NCT01342211, } \\
\text { NCT01592240, } \\
\text { NCT01350141 } \\
\end{array}$ \\
\hline LY-3015014 & $\begin{array}{l}\text { Eli Lilly and } \\
\text { Company }\end{array}$ & Phase 2 & NCT01890967 \\
\hline LGT209 & Novartis & Phase 1 & NCT01859455 \\
\hline PF-05335810 (RN317) & Pfizer & Phase 1 & NCT01720537 \\
\hline $\mathrm{J} 16$ & Pfizer & Preclinical & Liang et al. (2012) \\
\hline $\mathrm{J} 17$ & Pfizer & Preclinical & $\begin{array}{l}\text { Chaparro-Riggers } \\
\text { et al. (2012) }\end{array}$ \\
\hline 1B20 & Merck & Preclinical & Zhang et al. (2012c) \\
\hline 1D05-IgG2 & Merck & Preclinical & Ni et al. (2011) \\
\hline LGT210 & Novartis & Preclinical & Kramer (2013) \\
\hline LGT211 & Novartis & Preclinical & Kramer (2013) \\
\hline ALD-306 & $\begin{array}{l}\text { Alder } \\
\text { Biopharmaceuticals }\end{array}$ & Preclinical & Kramer (2013) \\
\hline
\end{tabular}

Alirocumab and evolocumab are currently further tested in 13 and 10 Phase 3 clinical trials, respectively (Table 1), for long-term efficacy and safety, either as monotherapy or on top of other lipid-modifying therapies and in various patient populations (e.g., subjects with primary hypercholesterolemia or mixed dyslipidemia, with high cardiovascular risk and with hyperlipidemia or mixed 
dyslipidemia, with heterozygous familial hypercholesterolemia, with clinically evident cardiovascular disease, with a 10-year Framingham risk score of $10 \%$ or less, undergoing coronary catheterization, who recently experienced an acute coronary syndrome, with statin intolerance). Among these Phase 3 clinical studies, two studies, which are conducted in numerous study centers across the United States, Canada, Western and Eastern Europe, South America, Australia, Africa, and Asia, will assess the effect of candidate drugs on the occurrence of cardiovascular events for up to 64 months in large-sized patient groups. Specifically, the effect of alirocumab (ODYSSEY Outcomes, NCT01663402) on the occurrence of cardiovascular events (composite endpoint of coronary heart disease (CHD) death, nonfatal myocardial infarction (MI), fatal and nonfatal ischemic stroke, unstable angina requiring hospitalization) is evaluated in 18,000 patients who have experienced an acute coronary syndrome event $4-16$ weeks prior to randomization and are treated with evidence-based medical and dietary management of dyslipidemia (time frame: up to month 64). Another objective of the study is the evaluation of the effect of alirocumab on secondary endpoints (any CHD event, major CHD event, any cardiovascular event, composite of all-cause mortality/nonfatal MI/nonfatal ischemic stroke, all-cause mortality), as well as on blood lipids and lipoprotein levels (time frame: up to month 64). In addition, the long-term safety and tolerability of alirocumab will be evaluated. In another large clinical trial (FOURIER, NCT01764633), the effect of evolocumab used in combination with statin therapy on additional LDL-C reduction and risk of cardiovascular death, MI, hospitalization for unstable angina, stroke, or coronary revascularization is evaluated in 22,500 patients with clinically evident cardiovascular disease. The primary endpoint is the time to cardiovascular death, MI, hospitalization for unstable angina, stroke, or coronary revascularization, whichever occurs first (time frame: 5 years). Another objective of the study is the evaluation of the effect of evolocumab on secondary endpoints, such as time to death by any cause, cardiovascular death, hospitalization for worsening heart failure, ischemic fatal or nonfatal stroke, and transient ischemic attack, whichever occurs first (time frame: 5 years).

\subsection{Approaches to Antibody Therapy for the Increase of HDL- Cholesterol Levels}

Numerous clinical and epidemiological studies have demonstrated an inverse association between HDL-cholesterol (HDL-C) levels and the risk of cardiovascular disease (Gordon et al. 1977; Assmann et al. 1996). Furthermore, HDL exerts a series of antiatherogenic properties (Navab et al. 2011). Thus, raising of HDL-C levels is expected to translate into a reduction of cardiovascular events and has led to serious efforts to develop new therapies that can increase the concentration of HDL-C. Therapeutic strategies using antibody-based blocking of proteins of the 
HDL metabolism pathway that result in increase of HDL-C levels are discussed below.

\subsubsection{Cholesteryl Ester Transfer Protein}

Cholesteryl ester transfer protein (CETP) promotes net mass transfer of cholesteryl esters from HDL to other plasma lipoprotein fractions (Barter and Rye 2012). Therefore, inhibition of CETP can increase the concentration of HDL-C and CETP inhibitors have been capable to increase HDL-C levels in preliminary clinical trials, while clinical outcome trials are ongoing (Barter and Rye 2012; Landmesser et al. 2012). The properties and effects of different CETP smallmolecule inhibitors that were observed in clinical trials are being described by Staels et al. in chapter "Emerging Small-Molecule Drugs."

An alternative approach involves the blocking of CETP action with an antibody, named CETi-1 (developed by AVANT Immunotherapeutics), raised against a dimerized synthetic peptide, including residues $461-476$ of human CETP and T cell epitope of tetanus toxoid (residues 830-843), and formulated with aluminumcontaining adjuvants (Davidson et al. 2003). In a Phase II study, CETi-1 was shown to be safe, and $>90 \%$ of treated patients with the highest dose of vaccine showed 1 year after vaccination with CETi-1 an immune response with an increase of HDL-C by $8 \%$ (Komori 2004). However, this trial failed to meet the primary endpoint of increasing plasma HDL-C concentrations in the vaccine-treated groups as compared to the placebo group, due to the low titers of antihuman CETP antibody achieved in a number of the vaccinated subjects, and CETi-1 is no longer in development (Komori 2004).

A few years ago, in order to improve the efficacy of the CETi-1 vaccine, AVANT Immunotherapeutics researchers examined in mice and rabbits the immunogenicity of CETi-1 with the coadministration of the investigational TLR9 agonist VaxImmune $^{\mathrm{TM}}$ (CPG 7909) as an adjuvant (Thomas et al. 2009). In parallel, they studied the immunogenicity of another anti-CETP antibody, the PADRE-CETP, raised against a monomeric peptide, in which a PADRE $\mathrm{T}$ cell epitope (aK-Cha-VAAWTLKAa) replaces the TT(830-843) T cell epitope of CETi-1, with or without the coadministration of VaxImmune ${ }^{\mathrm{TM}}$. The studies showed that PADRE T cell epitope is more potent than the TT(830-843) epitope in providing help for the anti-CETP antibody response and that the coadministration of VaxImmune $^{\mathrm{TM}}$ with either vaccine increased immunogenicity as measured by antibody response (Thomas et al. 2009). However, there is no information for the initiation of clinical trials using these new vaccination approaches up to date. Another recent CETP vaccination approach involves the ATH-03 anti-CETP antibody (developed by Affiris AG), using a small peptide fragment of the CETP protein acting as a B cell epitope (Kramer 2013), which has entered Phase 1 trials to assess its safety and immunogenicity (ClinicalTrials.gov Identifier: NCT01284582). 


\subsubsection{Endothelial Lipase}

Endothelial lipase (EL) is a phospholipase that participates in HDL metabolism and regulates HDL-C levels in humans and mice (Yasuda et al. 2010; Annema and Tietge 2011). Early studies in which EL was inhibited in wild-type, hepatic lipasedeficient, and human apolipoprotein (apo) A-I transgenic mice by intravenous infusion of a polyclonal inhibitory anti-mouse-EL antibody resulted in a 25-60\% increase in HDL-C levels in three mouse models, while triglyceride and non-HDLcholesterol levels were not changed (Jin et al. 2003). In human apoA-I transgenic mice, apoA-I levels were also increased and the HDL phospholipid turnover was retarded (Jin et al. 2003). Based on this and other studies in mice lacking EL activity, as well as on studies in humans expressing loss-of-function EL variants, the inhibition of EL in humans would be expected to raise plasma HDL-C levels (Brown et al. 2009; Ishida et al. 2003; Ma et al. 2003; Edmondson et al. 2009). Although the effect of EL inhibition in the reduction of atherosclerotic cardiovascular disease risk has not been proven (Yasuda et al. 2010; Annema and Tietge 2011), EL remains a potential target for pharmacological inhibition, possibly by antibodies against EL, as a novel strategy to raise HDL-C and reduce the risk of cardiovascular disease.

\subsection{Effect of Antibodies Used for the Treatment of Chronic Inflammatory Diseases on HDL Antiatherogenic Functions}

Patients with chronic inflammatory rheumatic diseases, such as rheumatoid arthritis and systemic lupus erythematosus, have increased risk for cardiovascular disease morbidity and mortality (Onat and Direskeneli 2012; Farragher and Bruce 2006; Popa et al. 2012). Various studies have shown that during the course of these chronic inflammatory conditions, the levels as well as the antiatherogenic properties of HDL are affected (Onat and Direskeneli 2012; Popa et al. 2012). Specifically, patients with rheumatoid arthritis and systemic lupus erythematosus were found to have proinflammatory HDL (McMahon et al. 2006; CharlesSchoeman et al. 2009). In addition, cholesterol efflux capacity of HDL was impaired in rheumatoid arthritis patients with high disease activity and was correlated with systemic inflammation and HDL's antioxidant capacity (CharlesSchoeman et al. 2012). Recommendations for the treatment of rheumatic diseases propose a tight control of the inflammatory process which probably will favorably impact the risk of cardiovascular disease. New therapeutics include antibodies designed to block inflammatory proteins or cells that are produced in abundance during the disease, such as TNF- $\alpha$, IL-6, or B cells (Onat and Direskeneli 2012; Popa et al. 2012). Anti-TNF therapy of rheumatoid arthritis patients with monoclonal antibody infliximab was shown to increase plasma paraoxonase-1 activity and to improve HDL antioxidative capacity, an effect that was sustained 6 months after anti-TNF therapy has been initiated (Popa et al. 2009). In addition, another recent study in rheumatoid arthritis patients treated with rituximab, a B cell depleting monoclonal antibody against the protein CD20, which is primarily found on the 
surface of B lymphocytes, showed beneficial changes in HDL composition (Raterman et al. 2013). Specifically, during 6 months of treatment with rituximab, HDL-associated serum amyloid A decreased in patients with good response to the therapy, rendering HDL from proatherogenic to less proatherogenic (Raterman et al. 2013). Future large-scale studies are needed to establish the value of monitoring HDL function during antibody therapy, as well as the impact of this therapy on cardiovascular disease risk of rheumatic disease patients and possibly other patients with coronary artery disease who remain at high vascular risk despite contemporary prevention strategies.

\subsection{Vaccines Against Atherosclerosis}

A large body of evidence has shown that atherosclerosis is a multifactorial, multiphase disease characterized by chronic inflammation and altered immune response. Therefore, approaches of active immunization have been developed to modulate atherosclerosis with promising results in preclinical studies. Many studies have reported reduced atherosclerosis in animal models after immunization using as antigens LDL (native or modified), apoB100 peptides, heat shock proteins, and other proteins or phospholipids associated with the initiation and progression of the atherosclerotic plaque.

Immunization with homologous LDL, oxLDL (copper-oxidized LDL), or MDA-LDL (LDL modified by malondialdehyde (MDA), an epitope of oxLDL) generated high titers of antibodies and reduced atherogenesis development in hypercholesterolemic rabbits, LDLR-deficient rabbits, or apoE-deficient mice (Palinski et al. 1995; Ameli et al. 1996; George et al. 1998; Zhou et al. 2001). Similar results were achieved using homologous plaque homogenates (containing immunogen(s) sharing epitopes on MDA-LDL, MDA-VLDL, and oxidized cardiolipin) as the antigen (Zhou et al. 2001). The generation of antibodies against oxidation epitopes in LDL has been proposed to inhibit the binding and uptake of oxLDL by macrophage scavenger receptors CD36 and SR-BI and therefore to reduce the formation of foam cells (Steinberg and Witztum 2010). In addition, induction of oral tolerance to oxLDL can induce a significant increase in CD4 $+\mathrm{CD} 25+\mathrm{Foxp} 3+\mathrm{T}_{\text {regs }}$ in spleen and mesenteric lymph nodes, and these cells specifically respond to oxLDL with increased TGF- $\beta$ production and significant attenuation of the initiation and progression of atherogenesis in LDLR-deficient mice (van Puijvelde et al. 2006). However, since atherosclerosis immune responses can been triggered against autoantigens, such as anti-oxLDL, all the efforts toward the development of a successful vaccine against oxLDL should result in the restoration of tolerance against autoantibodies and balance of pro- and antiatherogenic immune responses (Samson et al. 2012).

Screening of a library of 302 polypeptides covering the complete sequence of apoB-100, the major protein component in LDL, in their native state and after MDA modification, using pooled plasma derived from healthy control subjects, resulted in the identification of more than 100 different human antibodies reacting against 
MDA-modified apoB100 sequences (Fredrikson et al. 2003a). Immunization with apoB100 peptide sequences, against which high levels of IgG and IgM antibodies are present in healthy human controls, was found to reduce atherosclerosis in apoEdeficient mice by about $60 \%$ (Fredrikson et al. 2003b). Studies on the mechanisms underlying active immunization using a specific apoB100-related peptide, namely, the p210, indicated that the atheroprotective effect of immunization with this peptide is mediated via the activation of CD8+T cells (Chyu et al. 2012) and CD4+ CD25+Foxp3+ $\mathrm{T}_{\text {regs }}$ (Wigren et al. 2011).

Other approaches to reduce atherosclerosis involve the immunization with antigens other than LDL or apoB100-related peptides. Immunization of hypercholesterolemic rabbits with protein-free liposomes containing dimyristoyl phosphatidylcholine, dimyristoyl phosphatidylglycerol, cholesterol (71\%), and lipid A from Salmonella Minnesota R595 as adjuvant induced the generation of anticholesterol antibodies and reduced the diet-induced hypercholesterolemia and plaque formation (Alving et al. 1996). In another study, pneumococcal vaccination was also found to decrease the atherosclerotic lesion formation (Binder et al. 2003). The use of Streptococcus pneumoniae as an antigen was based on the finding that during the progression of atherosclerosis in apoE-deficient mice, autoantibodies against epitopes of oxLDL, and more specifically against the oxidized phospholipids, share complete genetic and structural identity with antibodies from the classic anti-phosphorylcholine B cell clone, T15, which protect against common infectious pathogens, including pneumococci (Shaw et al. 2000). The reduction of atherosclerosis in LDLR-deficient mice after immunization with $S$. pneumoniae suggested molecular mimicry between epitopes of oxLDL and $S$. pneumonia (Binder et al. 2003). In another recent study, it was found that $\mathrm{T}$ cell hybridomas from oxLDL-immunized human apoB100 transgenic mice responded against native LDL and purified apoB100, but not against oxLDL and expressed a single $\mathrm{T}$ cell receptor variable beta chain, TRBV31. Immunization of double human apoB100 transgenic and LDLR-deficient mice with a TRBV31-derived peptide generated anti-TRBV31 antibodies that blocked $\mathrm{T}$ cell recognition of apoB100 and reduced atherosclerosis (Hermansson et al. 2010).

In the last decade, various therapeutic approaches for reducing atherosclerosis by immunization were based on heat shock proteins (HSPs). HSPs, which are named according to their molecular weight, are a highly conserved group of proteins that have been implicated in atherogenesis (Kilic and Mandal 2012; Grundtman et al. 2011). Intracellularly, HSPs act as molecular chaperones and assist in the folding of misfolded proteins, but extracellularly, HSPs can promote immune responses. Immunization of rabbit or mouse atherosclerotic models with HSP65 resulted in conflicting results, with some studies showing induction of atherosclerotic lesions (Xu et al. 1992; George et al. 1999; Zhang et al. 2012d) and others reduction of atherosclerosis (Maron et al. 2002; Harats et al. 2002; Long et al. 2012; Klingenberg et al. 2012). Vaccination of high-cholesterol-fed atherosclerotic rabbits with a recombinant HSP65-CETP fusion protein resulted in production of more protective IL-10 and less adverse IFN- $\gamma$, reduction of total cholesterol and LDL-C levels, as well as decrease of the area of aortic lesions 
(Jun et al. 2012). In addition, the immunization of apoE-deficient or double apoB48- and LDLR-deficient mice with chimeric proteins containing apoB-100 and/or hHSP60 peptides resulted in the reduction of atherosclerotic lesions (Li et al. 2011; Lu et al. 2010).

Another target for the treatment of atherosclerosis by immunization involves a specific cell population, the vascular endothelial growth factor receptor 2 (VEGFR2)-overexpressing cells. Highly VEGFR2 expressing cells include proliferating endothelial cells that are involved in angiogenesis, a process that may be associated with the initiation and progression of atherosclerosis (Shi et al. 1998; Li et al. 2002; Moulton et al. 2003). Vaccination of apoE- or LDLRdeficient mice against VEGFR2 by an orally administered DNA vaccine, comprising a plasmid encoding murine VEGFR2 carried by live attenuated Salmonella typhimurium, resulted in a marked induction of CD8+ cytotoxic T cells specific for VEGFR2 and attenuated the initiation and progression of atherosclerosis (Hauer et al. 2007). Oral administration of another DNA vaccine, one against CD99, a membrane protein expressed on vascular endothelium overlying atherosclerotic plaques, also generated antigen-specific cytotoxic CD8+ $\mathrm{T}$ cells and reduced atherosclerosis in LDLR-deficient mice (van Wanrooij et al. 2008).

In a recent study of a potential treatment option for atherosclerosis, immunization of apoE-deficient mice with a virus-like particle-based vaccine against IL- $1 \alpha$, a cytokine exerting proinflammatory functions and implicated in the development of atherosclerosis (Kamari et al. 2007), reduced both the inflammatory reaction in the plaque and plaque progression (Tissot et al. 2013). A current Phase 3 clinical study that aims to test the inflammatory hypothesis of atherothrombosis has been designed to evaluate whether Canakinumab can reduce rates of recurrent MI, stroke, and cardiovascular death among stable patients with coronary artery disease who remain at high vascular risk due to persistent elevations of high-sensitivity C-reactive protein (CRP) ( $>2 \mathrm{mg} / \mathrm{L})$ despite contemporary secondary prevention strategies (Ridker et al. 2011). Canakinumab is a human monoclonal antibody that selectively neutralizes IL-1 $\beta$, a cytokine that exerts proinflammatory effects and has been implicated in the pathogenesis of atherothrombosis (Fearon and Fearon 2008). The study which is named Canakinumab Anti-inflammatory Thrombosis Outcomes Study (CANTOS, ClinicalTrials.gov Identifier: NCT01327846) will randomly allocate 17,200 patients to either placebo or to Canakinumab at doses of 50, 150, or $300 \mathrm{mg}$ every 3 months, administered subcutaneously, and all participants will be followed up over an estimated period of up to 4 years (Ridker et al. 2011). As part of the CANTOS study, a multinational Phase IIb randomized, placebo-controlled trial was conducted to evaluate the effects of Canakinumab agent on hemoglobin A1c, glucose, lipids, CRP, IL-6, and fibrinogen among 556 men and women with diabetes mellitus and high cardiovascular risk (Ridker et al. 2012). The patients were randomly allocated to subcutaneous placebo or to subcutaneous Canakinumab at doses of 5, 15, 50, or $150 \mathrm{mg}$ monthly and followed over 4 months. No effects were seen for hemoglobin A1c, glucose, insulin, LDL-C, HDL-C, or non-HDLcholesterol levels. By contrast, there were significant reductions in CRP, IL-6, and 
fibrinogen levels in both women and men. The CANTOS Investigative Group members support that these data provide a strong basis for the use of Canakinumab in humans as an approach to test whether therapeutic targeting of inflammation can reduce the risk of recurrent events in patients on current standard of care treatment after MI (Ridker et al. 2012).

\section{Conclusions}

Antisense oligonucleotide or gene therapy has been discussed for more than 30 years. The approval for commercial use of the first antisense oligonucleotide in 1998 by the FDA has catalyzed the development of these types of therapy for several diseases. Moreover, recent approvals of mipomersen or the gene therapy drug Glyvera have opened avenues for the use of these novel therapeutic approaches to treat lipid metabolism disorders. While miRNA and mAbs therapy to treat dyslipidemia have benefitted from previous existing technology, the recent clinical trials to target miR-122 through anti-miR technology and to target PCSK9 through mAbs technology will probably encourage the development of novel therapies to modulate HDL metabolism and function. mAbs are currently being investigated for their capacity to decrease LDL-C levels, increase HDL-C levels, and reduce the risk of cardiovascular events in clinical studies. Initial studies showed that these compounds are generally safe and well tolerated. Ongoing, large clinical studies will assess the long-term safety as well as the efficacy of these new antibody-based drugs in a wide range of dyslipidemic and cardiovascular disease patients. Even though the complex biological structure and functions of HDL are probably delaying the benefits of having a drug using any of these technologies in clinical care, ongoing preclinical or clinical studies using antisense oligonucleotides, miRNAs, or mAbs envision a bright future for the HDL field.

Acknowledgments Research by the groups of Drs Alberto Dávalos and Angeliki Chroni is supported by COST Action BM0904. Dr Angeliki Chroni's research is also supported by grants of the General Secretariat of Research and Technology of Greece (Grant Synergasia 09SYN-12897) and the Ministry of Education of Greece (Grant Thalis MIS 377286). Dr Alberto Dávalos' research is also supported by a grant from the Spanish Instituto de Salud Carlos III (FIS, PI11/ 00315).

Open Access This chapter is distributed under the terms of the Creative Commons Attribution Noncommercial License, which permits any noncommercial use, distribution, and reproduction in any medium, provided the original author(s) and source are credited.

\section{References}

Abifadel M, Varret M, Rabes JP, Allard D, Ouguerram K, Devillers M, Cruaud C, Benjannet S, Wickham L, Erlich D, Derre A, Villeger L, Farnier M, Beucler I, Bruckert E, Chambaz J, Chanu B, Lecerf JM, Luc G, Moulin P, Weissenbach J, Prat A, Krempf M, Junien C, Seidah NG, Boileau C (2003) Mutations in PCSK9 cause autosomal dominant hypercholesterolemia. Nat Genet 34:154-156 
Adlakha YK, Khanna S, Singh R, Singh VP, Agrawal A, Saini N (2013) Pro-apoptotic miRNA128-2 modulates ABCA1, ABCG1 and RXRalpha expression and cholesterol homeostasis. Cell Death Dis 4:e780

Alger HM, Brown JM, Sawyer JK, Kelley KL, Shah R, Wilson MD, Willingham MC, Rudel LL (2010) Inhibition of acyl-coenzyme A:cholesterol acyltransferase 2 (ACAT2) prevents dietary cholesterol-associated steatosis by enhancing hepatic triglyceride mobilization. J Biol Chem 285:14267-14274

Allen RM, Marquart TJ, Albert CJ, Suchy FJ, Wang DQ, Ananthanarayanan M, Ford DA, Baldan A (2012) miR-33 controls the expression of biliary transporters, and mediates statin- and dietinduced hepatotoxicity. EMBO Mol Med 4:882-895

Alving CR, Swartz GM Jr, Wassef NM, Ribas JL, Herderick EE, Virmani R, Kolodgie FD, Matyas GR, Cornhill JF (1996) Immunization with cholesterol-rich liposomes induces anti-cholesterol antibodies and reduces diet-induced hypercholesterolemia and plaque formation. J Lab Clin Med 127:40-49

Ameli S, Hultgardh-Nilsson A, Regnstrom J, Calara F, Yano J, Cercek B, Shah PK, Nilsson J (1996) Effect of immunization with homologous LDL and oxidized LDL on early atherosclerosis in hypercholesterolemic rabbits. Arterioscler Thromb Vasc Biol 16:1074-1079

Anderson RA, Joyce C, Davis M, Reagan JW, Clark M, Shelness GS, Rudel LL (1998) Identification of a form of acyl-CoA:cholesterol acyltransferase specific to liver and intestine in nonhuman primates. J Biol Chem 273:26747-26754

Annema W, Tietge UJ (2011) Role of hepatic lipase and endothelial lipase in high-density lipoprotein-mediated reverse cholesterol transport. Curr Atheroscler Rep 13:257-265

Arroyo JD, Chevillet JR, Kroh EM, Ruf IK, Pritchard CC, Gibson DF, Mitchell PS, Bennett CF, Pogosova-Agadjanyan EL, Stirewalt DL, Tait JF, Tewari M (2011) Argonaute2 complexes carry a population of circulating microRNAs independent of vesicles in human plasma. Proc Natl Acad Sci USA 108:5003-5008

Assmann G, Schulte H, von Eckardstein A, Huang Y (1996) High-density lipoprotein cholesterol as a predictor of coronary heart disease risk. The PROCAM experience and pathophysiological implications for reverse cholesterol transport. Atherosclerosis 124(Suppl):S11-S20

Baigent C, Keech A, Kearney PM, Blackwell L, Buck G, Pollicino C, Kirby A, Sourjina T, Peto R, Collins R, Simes R (2005) Efficacy and safety of cholesterol-lowering treatment: prospective meta-analysis of data from 90,056 participants in 14 randomised trials of statins. Lancet 366:1267-1278

Baigent C, Blackwell L, Emberson J, Holland LE, Reith C, Bhala N, Peto R, Barnes EH, Keech A, Simes J, Collins R (2010) Efficacy and safety of more intensive lowering of LDL cholesterol: a meta-analysis of data from 170,000 participants in 26 randomised trials. Lancet 376:1670-1681

Bartel DP (2009) MicroRNAs: target recognition and regulatory functions. Cell 136:215-233

Barter PJ, Rye KA (2012) Cholesteryl ester transfer protein inhibition as a strategy to reduce cardiovascular risk. J Lipid Res 53:1755-1766

Barter PJ, Caulfield M, Eriksson M, Grundy SM, Kastelein JJ, Komajda M, Lopez-Sendon J, Mosca L, Tardif JC, Waters DD, Shear CL, Revkin JH, Buhr KA, Fisher MR, Tall AR, Brewer B (2007) Effects of torcetrapib in patients at high risk for coronary events. N Engl J Med 357:2109-2122

Bell TA 3rd, Brown JM, Graham MJ, Lemonidis KM, Crooke RM, Rudel LL (2006) Liver-specific inhibition of acyl-coenzyme a:cholesterol acyltransferase 2 with antisense oligonucleotides limits atherosclerosis development in apolipoprotein B100-only low-density lipoprotein receptor $^{-/-}$mice. Arterioscler Thromb Vasc Biol 26:1814-1820

Bell TA, Graham MJ, Lee RG, Mullick AE, Fu W, Norris D, Crooke RM (2013) Antisense oligonucleotide inhibition of cholesteryl ester transfer protein enhances RCT in hyperlipidemic, CETP transgenic, $\mathrm{LDLr}^{-/-}$mice. J Lipid Res 54:2647-2657

Bennett CF, Swayze EE (2010) RNA targeting therapeutics: molecular mechanisms of antisense oligonucleotides as a therapeutic platform. Annu Rev Pharmacol Toxicol 50:259-293 
Binder CJ, Horkko S, Dewan A, Chang MK, Kieu EP, Goodyear CS, Shaw PX, Palinski W, Witztum JL, Silverman GJ (2003) Pneumococcal vaccination decreases atherosclerotic lesion formation: molecular mimicry between Streptococcus pneumoniae and oxidized LDL. Nat Med 9:736-743

Brett JO, Renault VM, Rafalski VA, Webb AE, Brunet A (2011) The microRNA cluster miR-106b $\sim 25$ regulates adult neural stem/progenitor cell proliferation and neuronal differentiation. Aging (Albany NY) 3:108-124

Brown JM, Bell TA 3rd, Alger HM, Sawyer JK, Smith TL, Kelley K, Shah R, Wilson MD, Davis MA, Lee RG, Graham MJ, Crooke RM, Rudel LL (2008) Targeted depletion of hepatic ACAT2-driven cholesterol esterification reveals a non-biliary route for fecal neutral sterol loss. J Biol Chem 283:10522-10534

Brown RJ, Edmondson AC, Griffon N, Hill TB, Fuki IV, Badellino KO, Li M, Wolfe ML, Reilly MP, Rader DJ (2009) A naturally occurring variant of endothelial lipase associated with elevated HDL exhibits impaired synthesis. J Lipid Res 50:1910-1916

Brown MS, Ye J, Goldstein JL (2010) Medicine. HDL miR-ed down by SREBP introns. Science 328:1495-1496

Calin GA, Dumitru CD, Shimizu M, Bichi R, Zupo S, Noch E, Aldler H, Rattan S, Keating M, Rai K, Rassenti L, Kipps T, Negrini M, Bullrich F, Croce CM (2002) Frequent deletions and down-regulation of micro- RNA genes miR15 and miR16 at 13q14 in chronic lymphocytic leukemia. Proc Natl Acad Sci USA 99:15524-15529

Campbell JM, Bacon TA, Wickstrom E (1990) Oligodeoxynucleoside phosphorothioate stability in subcellular extracts, culture media, sera and cerebrospinal fluid. J Biochem Biophys Methods 20:259-267

Catapano AL (2009) Perspectives on low-density lipoprotein cholesterol goal achievement. Curr Med Res Opin 25:431-447

Catapano AL, Papadopoulos N (2013) The safety of therapeutic monoclonal antibodies: implications for cardiovascular disease and targeting the PCSK9 pathway. Atherosclerosis 228:18-28

Cesana M, Cacchiarelli D, Legnini I, Santini T, Sthandier O, Chinappi M, Tramontano A, Bozzoni I (2011) A long noncoding RNA controls muscle differentiation by functioning as a competing endogenous RNA. Cell 147:358-369

Chan JC, Piper DE, Cao Q, Liu D, King C, Wang W, Tang J, Liu Q, Higbee J, Xia Z, Di Y, Shetterly S, Arimura Z, Salomonis H, Romanow WG, Thibault ST, Zhang R, Cao P, Yang XP, Yu T, Lu M, Retter MW, Kwon G, Henne K, Pan O, Tsai MM, Fuchslocher B, Yang E, Zhou L, Lee KJ, Daris M, Sheng J, Wang Y, Shen WD, Yeh WC, Emery M, Walker NP, Shan B, Schwarz M, Jackson SM (2009) A proprotein convertase subtilisin/kexin type 9 neutralizing antibody reduces serum cholesterol in mice and nonhuman primates. Proc Natl Acad Sci USA 106:9820-9825

Chaparro-Riggers J, Liang H, DeVay RM, Bai L, Sutton JE, Chen W, Geng T, Lindquist K, Casas MG, Boustany LM, Brown CL, Chabot J, Gomes B, Garzone P, Rossi A, Strop P, Shelton D, Pons J, Rajpal A (2012) Increasing serum half-life and extending cholesterol lowering in vivo by engineering antibody with $\mathrm{pH}$-sensitive binding to PCSK9. J Biol Chem 287:11090-11097

Charles-Schoeman C, Watanabe J, Lee YY, Furst DE, Amjadi S, Elashoff D, Park G, McMahon M, Paulus HE, Fogelman AM, Reddy ST (2009) Abnormal function of highdensity lipoprotein is associated with poor disease control and an altered protein cargo in rheumatoid arthritis. Arthritis Rheum 60:2870-2879

Charles-Schoeman C, Lee YY, Grijalva V, Amjadi S, FitzGerald J, Ranganath VK, Taylor M, McMahon M, Paulus HE, Reddy ST (2012) Cholesterol efflux by high density lipoproteins is impaired in patients with active rheumatoid arthritis. Ann Rheum Dis 71:1157-1162

Chen X, Liang H, Zhang J, Zen K, Zhang CY (2012) Secreted microRNAs: a new form of intercellular communication. Trends Cell Biol 22:125-132

Chistiakov DA, Sobenin IA, Orekhov AN (2012) Strategies to deliver microRNAs as potential therapeutics in the treatment of cardiovascular pathology. Drug Deliv 19:392-405 
Chyu KY, Zhao X, Dimayuga PC, Zhou J, Li X, Yano J, Lio WM, Chan LF, Kirzner J, Trinidad P, Cercek B, Shah PK (2012) CD8+ T cells mediate the athero-protective effect of immunization with an ApoB-100 peptide. PLoS ONE 7:e30780

Cirera-Salinas D, Pauta M, Allen RM, Salerno AG, Ramirez CM, Chamorro-Jorganes A, Wanschel AC, Lasuncion MA, Morales-Ruiz M, Suarez Y, Baldan A, Esplugues E, Fernandez-Hernando C (2012) Mir-33 regulates cell proliferation and cell cycle progression. Cell Cycle 11:922-933

Cohen J, Pertsemlidis A, Kotowski IK, Graham R, Garcia CK, Hobbs HH (2005) Low LDL cholesterol in individuals of African descent resulting from frequent nonsense mutations in PCSK9. Nat Genet 37:161-165

Cohen JC, Boerwinkle E, Mosley TH, Hobbs HH (2006) Sequence variations in PCSK9, low LDL, and protection against coronary heart disease. N Engl J Med 354:1264-1272

Cordes KR, Sheehy NT, White MP, Berry EC, Morton SU, Muth AN, Lee TH, Miano JM, Ivey KN, Srivastava D (2009) miR-145 and miR-143 regulate smooth muscle cell fate and plasticity. Nature 460:705-710

Davalos A, Fernandez-Hernando C (2013) From evolution to revolution: miRNAs as pharmacological targets for modulating cholesterol efflux and reverse cholesterol transport. Pharmacol Res 75:60-72

Davalos A, Suarez Y (2013) MiRNA-based therapy: from bench to bedside. Pharmacol Res 75:1-2

Davalos A, Goedeke L, Smibert P, Ramirez CM, Warrier NP, Andreo U, Cirera-Salinas D, Rayner K, Suresh U, Pastor-Pareja JC, Esplugues E, Fisher EA, Penalva LO, Moore KJ, Suarez Y, Lai EC, Fernandez-Hernando C (2011) miR-33a/b contribute to the regulation of fatty acid metabolism and insulin signaling. Proc Natl Acad Sci USA 108:9232-9237

Davidson MH, Maki K, Umporowicz D, Wheeler A, Rittershaus C, Ryan U (2003) The safety and immunogenicity of a CETP vaccine in healthy adults. Atherosclerosis 169:113-120

Davis S, Propp S, Freier SM, Jones LE, Serra MJ, Kinberger G, Bhat B, Swayze EE, Bennett CF, Esau C (2009) Potent inhibition of microRNA in vivo without degradation. Nucleic Acids Res 37:70-77

de Aguiar Vallim TQ, Tarling EJ, Kim T, Civelek M, Baldan A, Esau C, Edwards PA (2013) MicroRNA-144 regulates hepatic ATP binding cassette transporter A1 and plasma highdensity lipoprotein after activation of the nuclear receptor farnesoid $\mathrm{X}$ receptor. Circ Res 112:1602-1612

Desai NR, Kohli P, Giugliano RP, O’Donoghue ML, Somaratne R, Zhou J, Hoffman EB, Huang F, Rogers WJ, Wasserman SM, Scott R, Sabatine MS (2013) AMG145, a monoclonal antibody against proprotein convertase subtilisin kexin type 9 , significantly reduces lipoprotein(a) in hypercholesterolemic patients receiving statin therapy: an analysis from the LDL-C assessment with proprotein convertase subtilisin kexin type 9 monoclonal antibody inhibition combined with statin therapy (LAPLACE)-thrombolysis in myocardial infarction (TIMI) 57 trial. Circulation 128:962-969

Dias CS, Shaywitz AJ, Wasserman SM, Smith BP, Gao B, Stolman DS, Crispino CP, Smirnakis KV, Emery MG, Colbert A, Gibbs JP, Retter MW, Cooke BP, Uy ST, Matson M, Stein EA (2012) Effects of AMG 145 on low-density lipoprotein cholesterol levels: results from 2 randomized, double-blind, placebo-controlled, ascending-dose phase 1 studies in healthy volunteers and hypercholesterolemic subjects on statins. J Am Coll Cardiol 60:1888-1898

Edmondson AC, Brown RJ, Kathiresan S, Cupples LA, Demissie S, Manning AK, Jensen MK, Rimm EB, Wang J, Rodrigues A, Bamba V, Khetarpal SA, Wolfe ML, Derohannessian S, Li M, Reilly MP, Aberle J, Evans D, Hegele RA, Rader DJ (2009) Loss-of-function variants in endothelial lipase are a cause of elevated HDL cholesterol in humans. J Clin Invest 119:1042-1050

Elmen J, Thonberg H, Ljungberg K, Frieden M, Westergaard M, Xu Y, Wahren B, Liang Z, Orum H, Koch T, Wahlestedt C (2005) Locked nucleic acid (LNA) mediated improvements in siRNA stability and functionality. Nucleic Acids Res 33:439-447 
Elmen J, Lindow M, Schutz S, Lawrence M, Petri A, Obad S, Lindholm M, Hedtjarn M, Hansen HF, Berger U, Gullans S, Kearney P, Sarnow P, Straarup EM, Kauppinen S (2008) LNA-mediated microRNA silencing in non-human primates. Nature 452:896-899

Engel T, Lueken A, Bode G, Hobohm U, Lorkowski S, Schlueter B, Rust S, Cullen P, Pech M, Assmann G, Seedorf U (2004) ADP-ribosylation factor (ARF)-like 7 (ARL7) is induced by cholesterol loading and participates in apolipoprotein AI-dependent cholesterol export. FEBS Lett 566:241-246

Farragher TM, Bruce IN (2006) Cardiovascular risk in inflammatory rheumatic diseases: loose ends and common threads. J Rheumatol 33:2105-2107

Fearon WF, Fearon DT (2008) Inflammation and cardiovascular disease: role of the interleukin-1 receptor antagonist. Circulation 117:2577-2579

Flynt AS, Lai EC (2008) Biological principles of microRNA-mediated regulation: shared themes amid diversity. Nat Rev Genet 9:831-842

Fredrikson GN, Hedblad B, Berglund G, Alm R, Ares M, Cercek B, Chyu KY, Shah PK, Nilsson J (2003a) Identification of immune responses against aldehyde-modified peptide sequences in apoB associated with cardiovascular disease. Arterioscler Thromb Vasc Biol 23:872-878

Fredrikson GN, Soderberg I, Lindholm M, Dimayuga P, Chyu KY, Shah PK, Nilsson J (2003b) Inhibition of atherosclerosis in apoE-null mice by immunization with apoB-100 peptide sequences. Arterioscler Thromb Vasc Biol 23:879-884

Friedmann T, Roblin R (1972) Gene therapy for human genetic disease? Science 175:949-955

Gabriely G, Teplyuk NM, Krichevsky AM (2011) Context effect: microRNA-10b in cancer cell proliferation, spread and death. Autophagy 7:1384-1386

Geary RS, Watanabe TA, Truong L, Freier S, Lesnik EA, Sioufi NB, Sasmor H, Manoharan M, Levin AA (2001) Pharmacokinetic properties of 2'-O-(2-methoxyethyl)-modified oligonucleotide analogs in rats. J Pharmacol Exp Ther 296:890-897

George J, Afek A, Gilburd B, Levkovitz H, Shaish A, Goldberg I, Kopolovic Y, Wick G, Shoenfeld Y, Harats D (1998) Hyperimmunization of apo-E-deficient mice with homologous malondialdehyde low-density lipoprotein suppresses early atherogenesis. Atherosclerosis 138:147-152

George J, Shoenfeld Y, Afek A, Gilburd B, Keren P, Shaish A, Kopolovic J, Wick G, Harats D (1999) Enhanced fatty streak formation in C57BL/6 J mice by immunization with heat shock protein-65. Arterioscler Thromb Vasc Biol 19:505-510

Gerin I, Clerbaux LA, Haumont O, Lanthier N, Das AK, Burant CF, Leclercq IA, MacDougald OA, Bommer GT (2010) Expression of miR-33 from an SREBP2 intron inhibits cholesterol export and fatty acid oxidation. J Biol Chem 285:33652-33661

Giugliano RP, Desai NR, Kohli P, Rogers WJ, Somaratne R, Huang F, Liu T, Mohanavelu S, Hoffman EB, McDonald ST, Abrahamsen TE, Wasserman SM, Scott R, Sabatine MS (2012) Efficacy, safety, and tolerability of a monoclonal antibody to proprotein convertase subtilisin/ kexin type 9 in combination with a statin in patients with hypercholesterolaemia (LAPLACETIMI 57): a randomised, placebo-controlled, dose-ranging, phase 2 study. Lancet 380:2007-2017

Gonzalez-Carmona MA, Quasdorff M, Vogt A, Tamke A, Yildiz Y, Hoffmann P, Lehmann T, Bartenschlager R, Engels JW, Kullak-Ublick GA, Sauerbruch T, Caselmann WH (2013) Inhibition of hepatitis C virus RNA translation by antisense bile acid conjugated phosphorothioate modified oligodeoxynucleotides (ODN). Antiviral Res 97:49-59

Gordon T, Castelli WP, Hjortland MC, Kannel WB, Dawber TR (1977) High density lipoprotein as a protective factor against coronary heart disease. The Framingham study. Am J Med 62:707-714

Graham MJ, Lee RG, Bell TA 3rd, Fu W, Mullick AE, Alexander VJ, Singleton W, Viney N, Geary R, Su J, Baker BF, Burkey J, Crooke ST, Crooke RM (2013) Antisense oligonucleotide inhibition of apolipoprotein C-III reduces plasma triglycerides in rodents, nonhuman primates, and humans. Circ Res 112:1479-1490 
Grundtman C, Kreutmayer SB, Almanzar G, Wick MC, Wick G (2011) Heat shock protein 60 and immune inflammatory responses in atherosclerosis. Arterioscler Thromb Vasc Biol 31:960-968

Gumbiner B, Udata C, Joh T, Liang H, Wan H, Shelton D, Forgues P, Billote S, Pons J, Baum CM, Garzone PD (2012a) The effects of multiple dose administration of RN316 (PF-04950615), a humanized IgG2a monoclonal antibody binding proprotein convertase subtilisin kexin type 9, in hypercholesterolemic subjects. Circulation 126, A13524

Gumbiner B, Udata C, Joh T, Liang H, Wan H, Shelton D, Forgues P, Billote S, Pons J, Baum CM, Garzone PD (2012b) The Effects of Single Dose Administration of RN316 (PF-04950615), a Humanized IgG2a Monoclonal Antibody Binding Proprotein Convertase Subtilisin Kexin Type 9, in Hypercholesterolemic Subjects Treated with and without Atorvastatin. Circulation 126, A 13322

Guo H, Ingolia NT, Weissman JS, Bartel DP (2010) Mammalian microRNAs predominantly act to decrease target mRNA levels. Nature 466:835-840

Guo Y, Ying L, Tian Y, Yang P, Zhu Y, Wang Z, Qiu F, Lin J (2013) miR-144 downregulation increases bladder cancer cell proliferation by targeting EZH2 and regulating Wnt signaling. FEBS J 280:4531-4538

Gusarova V, Howard VG, Okamoto H, Koehler-Stec EM, Papadopoulos N, Murphy AJ, Yancopoulos GD, Stahl N, Sleeman MW (2012) Reduction of LDL cholesterol by a monoclonal antibody to PCSK9 in rodents and nonhuman primates. Clin Lipidol 7:737-743

Harats D, Yacov N, Gilburd B, Shoenfeld Y, George J (2002) Oral tolerance with heat shock protein 65 attenuates Mycobacterium tuberculosis-induced and high-fat-diet-driven atherosclerotic lesions. J Am Coll Cardiol 40:1333-1338

Hauer AD, van Puijvelde GH, Peterse N, de Vos P, van Weel V, van Wanrooij EJ, Biessen EA, Quax PH, Niethammer AG, Reisfeld RA, van Berkel TJ, Kuiper J (2007) Vaccination against VEGFR2 attenuates initiation and progression of atherosclerosis. Arterioscler Thromb Vasc Biol 27:2050-2057

Hebert SS, Horre K, Nicolai L, Bergmans B, Papadopoulou AS, Delacourte A, De Strooper B (2009) MicroRNA regulation of Alzheimer's Amyloid precursor protein expression. Neurobiol Dis 33:422-428

Helwak A, Kudla G, Dudnakova T, Tollervey D (2013) Mapping the human miRNA interactome by CLASH reveals frequent noncanonical binding. Cell 153:654-665

Hermansson A, Ketelhuth DF, Strodthoff D, Wurm M, Hansson EM, Nicoletti A, PaulssonBerne G, Hansson GK (2010) Inhibition of T cell response to native low-density lipoprotein reduces atherosclerosis. J Exp Med 207:1081-1093

Herrera-Merchan A, Cerrato C, Luengo G, Dominguez O, Piris MA, Serrano M, Gonzalez S (2010) miR-33-mediated downregulation of p53 controls hematopoietic stem cell self-renewal. Cell Cycle 9:3277-3285

Ho PC, Chang KC, Chuang YS, Wei LN (2011) Cholesterol regulation of receptor-interacting protein 140 via microRNA-33 in inflammatory cytokine production. FASEB J 25:1758-1766

Holasova S, Mojzisek M, Buncek M, Vokurkova D, Radilova H, Safarova M, Cervinka M, Haluza R (2005) Cholesterol conjugated oligonucleotide and LNA: a comparison of cellular and nuclear uptake by Hep2 cells enhanced by streptolysin-O. Mol Cell Biochem 276:61-69

Horie T, Ono K, Horiguchi M, Nishi H, Nakamura T, Nagao K, Kinoshita M, Kuwabara Y, Marusawa H, Iwanaga Y, Hasegawa K, Yokode M, Kimura T, Kita T (2010) MicroRNA-33 encoded by an intron of sterol regulatory element-binding protein 2 (Srebp2) regulates HDL in vivo. Proc Natl Acad Sci USA 107:17321-17326

Horie T, Baba O, Kuwabara Y, Chujo Y, Watanabe S, Kinoshita M, Horiguchi M, Nakamura T, Chonabayashi K, Hishizawa M, Hasegawa K, Kume N, Yokode M, Kita T, Kimura T, Ono K (2012) MicroRNA-33 deficiency reduces the progression of atherosclerotic plaque in ApoE(-/ -) mice. J Am Heart Assoc 1:e003376

Horie T, Nishino T, Baba O, Kuwabara Y, Nakao T, Nishiga M, Usami S, Izuhara M, Sowa N, Yahagi N, Shimano H, Matsumura S, Inoue K, Marusawa H, Nakamura T, Hasegawa K, 
Kume N, Yokode M, Kita T, Kimura T, Ono K (2013) MicroRNA-33 regulates sterol regulatory element-binding protein 1 expression in mice. Nat Commun 4:2883

Horton JD, Goldstein JL, Brown MS (2002) SREBPs: activators of the complete program of cholesterol and fatty acid synthesis in the liver. J Clin Invest 109:1125-1131

Hu Z, Shen WJ, Kraemer FB, Azhar S (2012) MicroRNAs 125a and 455 repress lipoproteinsupported steroidogenesis by targeting scavenger receptor class B type I in steroidogenic cells. Mol Cell Biol 32:5035-5045

Ishida T, Choi S, Kundu RK, Hirata K, Rubin EM, Cooper AD, Quertermous T (2003) Endothelial lipase is a major determinant of HDL level. J Clin Invest 111:347-355

Janssen HL, Reesink HW, Lawitz EJ, Zeuzem S, Rodriguez-Torres M, Patel K, van der Meer AJ, Patick AK, Chen A, Zhou Y, Persson R, King BD, Kauppinen S, Levin AA, Hodges MR (2013) Treatment of HCV infection by targeting microRNA. N Engl J Med 368:1685-1694

Jin W, Millar JS, Broedl U, Glick JM, Rader DJ (2003) Inhibition of endothelial lipase causes increased HDL cholesterol levels in vivo. J Clin Invest 111:357-362

Johannsen TH, Frikke-Schmidt R, Schou J, Nordestgaard BG, Tybjaerg-Hansen A (2012) Genetic inhibition of CETP, ischemic vascular disease and mortality, and possible adverse effects. $\mathrm{J}$ Am Coll Cardiol 60:2041-2048

Jun L, Jie L, Dongping Y, Xin Y, Taiming L, Rongyue C, Jie W, Jingjing L (2012) Effects of nasal immunization of multi-target preventive vaccines on atherosclerosis. Vaccine 30:1029-1037

Kamari Y, Werman-Venkert R, Shaish A, Werman A, Harari A, Gonen A, Voronov E, Grosskopf I, Sharabi Y, Grossman E, Iwakura Y, Dinarello CA, Apte RN, Harats D (2007) Differential role and tissue specificity of interleukin-1alpha gene expression in atherogenesis and lipid metabolism. Atherosclerosis 195:31-38

Kang MH, Zhang LH, Wijesekara N, de Haan W, Butland S, Bhattacharjee A, Hayden MR (2013) Regulation of ABCA1 protein expression and function in hepatic and pancreatic islet cells by miR-145. Arterioscler Thromb Vasc Biol 33:2724-2732

Karinaga R, Anada T, Minari J, Mizu M, Koumoto K, Fukuda J, Nakazawa K, Hasegawa T, Numata M, Shinkai S, Sakurai K (2006) Galactose-PEG dual conjugation of beta-(1->3)-Dglucan schizophyllan for antisense oligonucleotides delivery to enhance the cellular uptake. Biomaterials 27:1626-1635

Kastelein JJ, Wedel MK, Baker BF, Su J, Bradley JD, Yu RZ, Chuang E, Graham MJ, Crooke RM (2006) Potent reduction of apolipoprotein B and low-density lipoprotein cholesterol by shortterm administration of an antisense inhibitor of apolipoprotein B. Circulation 114:1729-1735

Kilic A, Mandal K (2012) Heat shock proteins: pathogenic role in atherosclerosis and potential therapeutic implications. Autoimmune Dis 2012:502813

Kim J, Yoon H, Ramirez CM, Lee SM, Hoe HS, Fernandez-Hernando C (2012) MiR-106b impairs cholesterol efflux and increases Abeta levels by repressing ABCA1 expression. Exp Neurol 235:476-483

Klingenberg R, Ketelhuth DF, Strodthoff D, Gregori S, Hansson GK (2012) Subcutaneous immunization with heat shock protein-65 reduces atherosclerosis in Apoe(-)/(-) mice. Immunobiology 217:540-547

Komori T (2004) CETi-1. AVANT. Curr Opin Investig Drugs 5:334-338

Koren MJ, Scott R, Kim JB, Knusel B, Liu T, Lei L, Bolognese M, Wasserman SM (2012) Efficacy, safety, and tolerability of a monoclonal antibody to proprotein convertase subtilisin/ kexin type 9 as monotherapy in patients with hypercholesterolaemia (MENDEL): a randomised, double-blind, placebo-controlled, phase 2 study. Lancet 380:1995-2006

Kramer W (2013) Novel drug approaches in development for the treatment of lipid disorders. Exp Clin Endocrinol Diabetes 121:567-580

Krol J, Loedige I, Filipowicz W (2010) The widespread regulation of microRNA biogenesis, function and decay. Nat Rev Genet 11:597-610

Krutzfeldt J, Rajewsky N, Braich R, Rajeev KG, Tuschl T, Manoharan M, Stoffel M (2005) Silencing of microRNAs in vivo with 'antagomirs'. Nature 438:685-689 
Krutzfeldt J, Kuwajima S, Braich R, Rajeev KG, Pena J, Tuschl T, Manoharan M, Stoffel M (2007) Specificity, duplex degradation and subcellular localization of antagomirs. Nucleic Acids Res 35:2885-2892

Kumar R, Singh SK, Koshkin AA, Rajwanshi VK, Meldgaard M, Wengel J (1998) The first analogues of LNA (locked nucleic acids): phosphorothioate-LNA and $2^{\prime}$-thio-LNA. Bioorg Med Chem Lett 8:2219-2222

Kuo CY, Lin YC, Yang JJ, Yang VC (2011) Interaction abolishment between mutant caveolin-1 (Delta62-100) and ABCA1 reduces HDL-mediated cellular cholesterol efflux. Biochem Biophys Res Commun 414:337-343

Kuusi T, Saarinen P, Nikkila EA (1980) Evidence for the role of hepatic endothelial lipase in the metabolism of plasma high density lipoprotein2 in man. Atherosclerosis 36:589-593

Lagos-Quintana M, Rauhut R, Yalcin A, Meyer J, Lendeckel W, Tuschl T (2002) Identification of tissue-specific microRNAs from mouse. Curr Biol 12:735-739

Lambert G, Sjouke B, Choque B, Kastelein JJ, Hovingh GK (2012) The PCSK9 decade. J Lipid Res 53:2515-2524

Landmesser U, von Eckardstein A, Kastelein J, Deanfield J, Luscher TF (2012) Increasing highdensity lipoprotein cholesterol by cholesteryl ester transfer protein-inhibition: a rocky road and lessons learned? The early demise of the dal-HEART programme. Eur Heart J 33:1712-1715

Lanford RE, Hildebrandt-Eriksen ES, Petri A, Persson R, Lindow M, Munk ME, Kauppinen S, Orum H (2010) Therapeutic silencing of microRNA-122 in primates with chronic hepatitis C virus infection. Science 327:198-201

Langlois RA, Shapiro JS, Pham AM, tenOever BR (2012) In vivo delivery of cytoplasmic RNA virus-derived miRNAs. Mol Ther 20:367-375

Lee RG, Fu W, Graham MJ, Mullick AE, Sipe D, Gattis D, Bell TA, Booten S, Crooke RM (2013a) Comparison of the pharmacological profiles of murine antisense oligonucleotides targeting apolipoprotein $\mathrm{B}$ and microsomal triglyceride transfer protein. J Lipid Res 54:602-614

Lee SH, Castagner B, Leroux JC (2013b) Is there a future for cell-penetrating peptides in oligonucleotide delivery? Eur J Pharm Biopharm 85:5-11

Li Y, Wang MN, Li H, King KD, Bassi R, Sun H, Santiago A, Hooper AT, Bohlen P, Hicklin DJ (2002) Active immunization against the vascular endothelial growth factor receptor flk1 inhibits tumor angiogenesis and metastasis. J Exp Med 195:1575-1584

Li J, Zhao X, Zhang S, Wang S, Du P, Qi G (2011) ApoB-100 and HSP60 peptides exert a synergetic role in inhibiting early atherosclerosis in immunized ApoE-null mice. Protein Pept Lett 18:733-740

Liang H, Chaparro-Riggers J, Strop P, Geng T, Sutton JE, Tsai D, Bai L, Abdiche Y, Dilley J, Yu J, Wu S, Chin SM, Lee NA, Rossi A, Lin JC, Rajpal A, Pons J, Shelton DL (2012) Proprotein convertase substilisin/kexin type 9 antagonism reduces low-density lipoprotein cholesterol in statin-treated hypercholesterolemic nonhuman primates. J Pharmacol Exp Ther 340:228-236

Long J, Lin J, Yang X, Yuan D, Wu J, Li T, Cao R, Liu J (2012) Nasal immunization with different forms of heat shock protein-65 reduced high-cholesterol-diet-driven rabbit atherosclerosis. Int Immunopharmacol 13:82-87

Lu X, Chen D, Endresz V, Xia M, Faludi I, Burian K, Szabo A, Csanadi A, Miczak A, Gonczol E, Kakkar V (2010) Immunization with a combination of ApoB and HSP60 epitopes significantly reduces early atherosclerotic lesion in Apobtm2SgyLdlrtm1Her/J mice. Atherosclerosis 212:472-480

Ma K, Cilingiroglu M, Otvos JD, Ballantyne CM, Marian AJ, Chan L (2003) Endothelial lipase is a major genetic determinant for high-density lipoprotein concentration, structure, and metabolism. Proc Natl Acad Sci USA 100:2748-2753

Marcus-Sekura CJ, Woerner AM, Shinozuka K, Zon G, Quinnan GV (1987) Comparative inhibition of chloramphenicol acetyltransferase gene expression by antisense oligonucleotide analogues having alkyl phosphotriester, methylphosphonate and phosphorothioate linkages. Nucleic Acids Res 15:5749-5763 
Maron R, Sukhova G, Faria AM, Hoffmann E, Mach F, Libby P, Weiner HL (2002) Mucosal administration of heat shock protein-65 decreases atherosclerosis and inflammation in aortic arch of low-density lipoprotein receptor-deficient mice. Circulation 106:1708-1715

Marquart TJ, Allen RM, Ory DS, Baldan A (2010) miR-33 links SREBP-2 induction to repression of sterol transporters. Proc Natl Acad Sci USA 107:12228-12232

Marquart TJ, Wu J, Lusis AJ, Baldan A (2013) Anti-miR-33 therapy does not alter the progression of atherosclerosis in low-density lipoprotein receptor-deficient mice. Arterioscler Thromb Vasc Biol 33:455-458

Mayne J, Dewpura T, Raymond A, Cousins M, Chaplin A, Lahey KA, Lahaye SA, Mbikay M, Ooi TC, Chretien M (2008) Plasma PCSK9 levels are significantly modified by statins and fibrates in humans. Lipids Health Dis 7:22

McKenney JM, Koren MJ, Kereiakes DJ, Hanotin C, Ferrand AC, Stein EA (2012) Safety and efficacy of a monoclonal antibody to proprotein convertase subtilisin/kexin type 9 serine protease, SAR236553/REGN727, in patients with primary hypercholesterolemia receiving ongoing stable atorvastatin therapy. J Am Coll Cardiol 59:2344-2353

McMahon M, Grossman J, FitzGerald J, Dahlin-Lee E, Wallace DJ, Thong BY, Badsha H, Kalunian K, Charles C, Navab M, Fogelman AM, Hahn BH (2006) Proinflammatory highdensity lipoprotein as a biomarker for atherosclerosis in patients with systemic lupus erythematosus and rheumatoid arthritis. Arthritis Rheum 54:2541-2549

Mencia A, Modamio-Hoybjor S, Redshaw N, Morin M, Mayo-Merino F, Olavarrieta L, Aguirre LA, del Castillo I, Steel KP, Dalmay T, Moreno F, Moreno-Pelayo MA (2009) Mutations in the seed region of human miR-96 are responsible for nonsyndromic progressive hearing loss. Nat Genet 41:609-613

Mendell JT, Olson EN (2012) MicroRNAs in stress signaling and human disease. Cell 148:1172-1187

Miyazaki Y, Adachi H, Katsuno M, Minamiyama M, Jiang YM, Huang Z, Doi H, Matsumoto S, Kondo N, Iida M, Tohnai G, Tanaka F, Muramatsu S, Sobue G (2012) Viral delivery of miR-196a ameliorates the SBMA phenotype via the silencing of CELF2. Nat Med 18:1136-1141

Monia BP, Lesnik EA, Gonzalez C, Lima WF, McGee D, Guinosso CJ, Kawasaki AM, Cook PD, Freier SM (1993) Evaluation of $2^{\prime}$-modified oligonucleotides containing $2^{\prime}$-deoxy gaps as antisense inhibitors of gene expression. J Biol Chem 268:14514-14522

Moulton KS, Vakili K, Zurakowski D, Soliman M, Butterfield C, Sylvin E, Lo KM, Gillies S, Javaherian K, Folkman J (2003) Inhibition of plaque neovascularization reduces macrophage accumulation and progression of advanced atherosclerosis. Proc Natl Acad Sci USA 100:4736-4741

Najafi-Shoushtari SH, Kristo F, Li Y, Shioda T, Cohen DE, Gerszten RE, Naar AM (2010) MicroRNA-33 and the SREBP host genes cooperate to control cholesterol homeostasis. Science 328:1566-1569

Navab M, Reddy ST, Van Lenten BJ, Fogelman AM (2011) HDL and cardiovascular disease: atherogenic and atheroprotective mechanisms. Nat Rev Cardiol 8:222-232

Nelson ER, Wardell SE, Jasper JS, Park S, Suchindran S, Howe MK, Carver NJ, Pillai RV, Sullivan PM, Sondhi V, Umetani M, Geradts J, McDonnell DP (2013) 27-Hydroxycholesterol links hypercholesterolemia and breast cancer pathophysiology. Science 342:1094-1098

Ni YG, Di MS, Condra JH, Peterson LB, Wang W, Wang F, Pandit S, Hammond HA, Rosa R, Cummings RT, Wood DD, Liu X, Bottomley MJ, Shen X, Cubbon RM, Wang SP, Johns DG, Volpari C, Hamuro L, Chin J, Huang L, Zhao JZ, Vitelli S, Haytko P, Wisniewski D, Mitnaul LJ, Sparrow CP, Hubbard B, Carfi A, Sitlani A (2011) A PCSK9-binding antibody that structurally mimics the EGF(A) domain of LDL-receptor reduces LDL cholesterol in vivo. J Lipid Res 52:78-86

Nissen SE, Tuzcu EM, Brewer HB, Sipahi I, Nicholls SJ, Ganz P, Schoenhagen P, Waters DD, Pepine CJ, Crowe TD, Davidson MH, Deanfield JE, Wisniewski LM, Hanyok JJ, Kassalow LM (2006) Effect of ACAT inhibition on the progression of coronary atherosclerosis. N Engl J Med 354:1253-1263 
Nohata N, Hanazawa T, Kikkawa N, Mutallip M, Fujimura L, Yoshino H, Kawakami K, Chiyomaru T, Enokida H, Nakagawa M, Okamoto Y, Seki N (2011) Caveolin-1 mediates tumor cell migration and invasion and its regulation by miR-133a in head and neck squamous cell carcinoma. Int J Oncol 38:209-217

Obad S, dos Santos CO, Petri A, Heidenblad M, Broom O, Ruse C, Fu C, Lindow M, Stenvang J, Straarup EM, Hansen HF, Koch T, Pappin D, Hannon GJ, Kauppinen S (2011) Silencing of microRNA families by seed-targeting tiny LNAs. Nat Genet 43:371-378

Oehlke J, Birth P, Klauschenz E, Wiesner B, Beyermann M, Oksche A, Bienert M (2002) Cellular uptake of antisense oligonucleotides after complexing or conjugation with cell-penetrating model peptides. Eur J Biochem 269:4025-4032

Onat A, Direskeneli H (2012) Excess cardiovascular risk in inflammatory rheumatic diseases: pathophysiology and targeted therapy. Curr Pharm Des 18:1465-1477

Orom UA, Nielsen FC, Lund AH (2008) MicroRNA-10a binds the $5^{\prime}$ UTR of ribosomal protein mRNAs and enhances their translation. Mol Cell 30:460-471

Ouimet M, Franklin V, Mak E, Liao X, Tabas I, Marcel YL (2011) Autophagy regulates cholesterol efflux from macrophage foam cells via lysosomal acid lipase. Cell Metab 13:655-667

Palinski W, Miller E, Witztum JL (1995) Immunization of low density lipoprotein (LDL) receptordeficient rabbits with homologous malondialdehyde-modified LDL reduces atherogenesis. Proc Natl Acad Sci USA 92:821-825

Pallan PS, Allerson CR, Berdeja A, Seth PP, Swayze EE, Prakash TP, Egli M (2012) Structure and nuclease resistance of $2^{\prime}, 4^{\prime}$-constrained $2^{\prime}$-O-methoxyethyl (cMOE) and 2'-O-ethyl (cEt) modified DNAs. Chem Commun (Camb) 48:8195-8197

Piao L, Zhang M, Datta J, Xie X, Su T, Li H, Teknos TN, Pan Q (2012) Lipid-based nanoparticle delivery of Pre-miR-107 inhibits the tumorigenicity of head and neck squamous cell carcinoma. Mol Ther 20:1261-1269

Poliseno L, Salmena L, Zhang J, Carver B, Haveman WJ, Pandolfi PP (2010) A codingindependent function of gene and pseudogene mRNAs regulates tumour biology. Nature 465:1033-1038

Popa C, van Tits LJ, Barrera P, Lemmers HL, van den Hoogen FH, van Riel PL, Radstake TR, Netea MG, Roest M, Stalenhoef AF (2009) Anti-inflammatory therapy with tumour necrosis factor alpha inhibitors improves high-density lipoprotein cholesterol antioxidative capacity in rheumatoid arthritis patients. Ann Rheum Dis 68:868-872

Popa CD, Arts E, Fransen J, van Riel PL (2012) Atherogenic index and high-density lipoprotein cholesterol as cardiovascular risk determinants in rheumatoid arthritis: the impact of therapy with biologicals. Mediat Inflamm 2012:785946

Prakash TP, Allerson CR, Dande P, Vickers TA, Sioufi N, Jarres R, Baker BF, Swayze EE, Griffey RH, Bhat B (2005) Positional effect of chemical modifications on short interference RNA activity in mammalian cells. J Med Chem 48:4247-4253

Qian P, Banerjee A, Wu ZS, Zhang X, Wang H, Pandey V, Zhang WJ, Lv XF, Tan S, Lobie PE, Zhu T (2012) Loss of SNAIL regulated miR-128-2 on chromosome 3p22.3 targets multiple stem cell factors to promote transformation of mammary epithelial cells. Cancer Res 72:6036-6050

Raal FJ, Santos RD, Blom DJ, Marais AD, Charng MJ, Cromwell WC, Lachmann RH, Gaudet D, Tan JL, Chasan-Taber S, Tribble DL, Flaim JD, Crooke ST (2010) Mipomersen, an apolipoprotein B synthesis inhibitor, for lowering of LDL cholesterol concentrations in patients with homozygous familial hypercholesterolaemia: a randomised, double-blind, placebo-controlled trial. Lancet 375:998-1006

Raal F, Scott R, Somaratne R, Bridges I, Li G, Wasserman SM, Stein EA (2012) Low-density lipoprotein cholesterol-lowering effects of AMG 145, a monoclonal antibody to proprotein convertase subtilisin/kexin type 9 serine protease in patients with heterozygous familial hypercholesterolemia: the Reduction of LDL-C with PCSK9 Inhibition in Heterozygous Familial Hypercholesterolemia Disorder (RUTHERFORD) randomized trial. Circulation 126:2408-2417 
Ramirez CM, Davalos A, Goedeke L, Salerno AG, Warrier N, Cirera-Salinas D, Suarez Y, Fernandez-Hernando C (2011) MicroRNA-758 regulates cholesterol efflux through posttranscriptional repression of ATP-binding cassette transporter A1. Arterioscler Thromb Vasc Biol 31:2707-2714

Ramirez CM, Rotllan N, Vlassov AV, Davalos A, Li M, Goedeke L, Aranda JF, Cirera-Salinas D, Araldi E, Salerno A, Wanschel A, Zavadil J, Castrillo A, Kim J, Suarez Y, FernandezHernando C (2013) Control of cholesterol metabolism and plasma high-density lipoprotein levels by microRNA-144. Circ Res 112:1592-1601

Raterman HG, Levels H, Voskuyl AE, Lems WF, Dijkmans BA, Nurmohamed MT (2013) HDL protein composition alters from proatherogenic into less atherogenic and proinflammatory in rheumatoid arthritis patients responding to rituximab. Ann Rheum Dis 72:560-565

Rayner KJ, Suarez Y, Davalos A, Parathath S, Fitzgerald ML, Tamehiro N, Fisher EA, Moore KJ, Fernandez-Hernando C (2010) MiR-33 contributes to the regulation of cholesterol homeostasis. Science 328:1570-1573

Rayner KJ, Esau CC, Hussain FN, McDaniel AL, Marshall SM, van Gils JM, Ray TD, Sheedy FJ, Goedeke L, Liu X, Khatsenko OG, Kaimal V, Lees CJ, Fernandez-Hernando C, Fisher EA, Temel RE, Moore KJ (2011a) Inhibition of miR-33a/b in non-human primates raises plasma HDL and lowers VLDL triglycerides. Nature 478:404-407

Rayner KJ, Sheedy FJ, Esau CC, Hussain FN, Temel RE, Parathath S, van Gils JM, Rayner AJ, Chang AN, Suarez Y, Fernandez-Hernando C, Fisher EA, Moore KJ (2011b) Antagonism of miR-33 in mice promotes reverse cholesterol transport and regression of atherosclerosis. J Clin Invest 121:2921-2931

Ridker PM, Thuren T, Zalewski A, Libby P (2011) Interleukin-1beta inhibition and the prevention of recurrent cardiovascular events: rationale and design of the canakinumab anti-inflammatory thrombosis outcomes study (CANTOS). Am Heart J 162:597-605

Ridker PM, Howard CP, Walter V, Everett B, Libby P, Hensen J, Thuren T (2012) Effects of interleukin-1 beta inhibition with canakinumab on hemoglobin A1c, lipids, C-reactive protein, interleukin-6, and fibrinogen: a phase IIb randomized, placebo-controlled trial. Circulation 126:2739-2748

Roth EM, McKenney JM, Hanotin C, Asset G, Stein EA (2012) Atorvastatin with or without an antibody to PCSK9 in primary hypercholesterolemia. N Engl J Med 367:1891-1900

Rottiers V, Obad S, Petri A, McGarrah R, Lindholm MW, Black JC, Sinha S, Goody RJ, Lawrence MS, Delemos AS, Hansen HF, Whittaker S, Henry S, Brookes R, Najafi-Shoushtari SH, Chung RT, Whetstine JR, Gerszten RE, Kauppinen S, Naar AM (2013) Pharmacological inhibition of a MicroRNA family in nonhuman primates by a seed-targeting 8-Mer AntimiR. Sci Transl Med 5:212ra162

Ryan BM, Robles AI, Harris CC (2010) Genetic variation in microRNA networks: the implications for cancer research. Nat Rev Cancer 10:389-402

Salmena L, Poliseno L, Tay Y, Kats L, Pandolfi PP (2011) A ceRNA hypothesis: the Rosetta Stone of a hidden RNA language? Cell 146:353-358

Samson S, Mundkur L, Kakkar VV (2012) Immune response to lipoproteins in atherosclerosis. Cholesterol 2012:571846

Schaefer EJ (2013) Effects of cholesteryl ester transfer protein inhibitors on human lipoprotein metabolism: why have they failed in lowering coronary heart disease risk? Curr Opin Lipidol 24:259-264

Schnall-Levin M, Zhao Y, Perrimon N, Berger B (2010) Conserved microRNA targeting in Drosophila is as widespread in coding regions as in $3^{\prime}$ UTRs. Proc Natl Acad Sci USA 107:15751-15756

Sehgal A, Vaishnaw A, Fitzgerald K (2013) Liver as a target for oligonucleotide therapeutics. J Hepatol 59:1354-1359

Selbach M, Schwanhausser B, Thierfelder N, Fang Z, Khanin R, Rajewsky N (2008) Widespread changes in protein synthesis induced by microRNAs. Nature 455:58-63 
Seth PP, Vasquez G, Allerson CA, Berdeja A, Gaus H, Kinberger GA, Prakash TP, Migawa MT, Bhat B, Swayze EE (2010) Synthesis and biophysical evaluation of $2^{\prime}, 4^{\prime}$-constrained $2^{\prime} \mathrm{O}$ methoxyethyl and $2^{\prime}, 4^{\prime}$-constrained $2^{\prime}$ O-ethyl nucleic acid analogues. $\mathrm{J}$ Org Chem 75:1569-1581

Shaw PX, Horkko S, Chang MK, Curtiss LK, Palinski W, Silverman GJ, Witztum JL (2000) Natural antibodies with the T15 idiotype may act in atherosclerosis, apoptotic clearance, and protective immunity. J Clin Invest 105:1731-1740

Shi Q, Rafii S, Wu MH, Wijelath ES, Yu C, Ishida A, Fujita Y, Kothari S, Mohle R, Sauvage LR, Moore MA, Storb RF, Hammond WP (1998) Evidence for circulating bone marrow-derived endothelial cells. Blood 92:362-367

Singaraja RR, Sivapalaratnam S, Hovingh K, Dube MP, Castro-Perez J, Collins HL, Adelman SJ, Riwanto M, Manz J, Hubbard B, Tietjen I, Wong K, Mitnaul LJ, van Heek M, Lin L, Roddy TA, McEwen J, Dallinge-Thie G, van Vark-van der Zee L, Verwoert G, Winther M, van Duijn C, Hofman A, Trip MD, Marais AD, Asztalos B, Landmesser U, Sijbrands E, Kastelein JJ, Hayden MR (2013) The impact of partial and complete loss-of-function mutations in endothelial lipase on high-density lipoprotein levels and functionality in humans. Circ Cardiovasc Genet 6:54-62

Singh Y, Murat P, Defrancq E (2010) Recent developments in oligonucleotide conjugation. Chem Soc Rev 39:2054-2070

Small EM, Olson EN (2011) Pervasive roles of microRNAs in cardiovascular biology. Nature 469:336-342

Stein EA, Gipe D, Bergeron J, Gaudet D, Weiss R, Dufour R, Wu R, Pordy R (2012a) Effect of a monoclonal antibody to PCSK9, REGN727/SAR236553, to reduce low-density lipoprotein cholesterol in patients with heterozygous familial hypercholesterolaemia on stable statin dose with or without ezetimibe therapy: a phase 2 randomised controlled trial. Lancet 380:29-36

Stein EA, Mellis S, Yancopoulos GD, Stahl N, Logan D, Smith WB, Lisbon E, Gutierrez M, Webb C, Wu R, Du Y, Kranz T, Gasparino E, Swergold GD (2012b) Effect of a monoclonal antibody to PCSK9 on LDL cholesterol. N Engl J Med 366:1108-1118

Steinberg D, Witztum JL (2010) Oxidized low-density lipoprotein and atherosclerosis. Arterioscler Thromb Vasc Biol 30:2311-2316

Sugano M, Makino N (1996) Changes in plasma lipoprotein cholesterol levels by antisense oligodeoxynucleotides against cholesteryl ester transfer protein in cholesterol-fed rabbits. J Biol Chem 271:19080-19083

Sugano M, Makino N, Sawada S, Otsuka S, Watanabe M, Okamoto H, Kamada M, Mizushima A (1998) Effect of antisense oligonucleotides against cholesteryl ester transfer protein on the development of atherosclerosis in cholesterol-fed rabbits. J Biol Chem 273:5033-5036

Sullivan D, Olsson AG, Scott R, Kim JB, Xue A, Gebski V, Wasserman SM, Stein EA (2012) Effect of a monoclonal antibody to PCSK9 on low-density lipoprotein cholesterol levels in statin-intolerant patients: the GAUSS randomized trial. JAMA 308:2497-2506

Sun D, Zhang J, Xie J, Wei W, Chen M, Zhao X (2012) MiR-26 controls LXR-dependent cholesterol efflux by targeting ABCA1 and ARL7. FEBS Lett 586:1472-1479

Swayze EE, Siwkowski AM, Wancewicz EV, Migawa MT, Wyrzykiewicz TK, Hung G, Monia BP, Bennett CF (2007) Antisense oligonucleotides containing locked nucleic acid improve potency but cause significant hepatotoxicity in animals. Nucleic Acids Res 35:687-700

Tay Y, Zhang J, Thomson AM, Lim B, Rigoutsos I (2008) MicroRNAs to Nanog, Oct4 and Sox2 coding regions modulate embryonic stem cell differentiation. Nature 455:1124-1128

Thomas LJ, Hammond RA, Forsberg EM, Geoghegan-Barek KM, Karalius BH, Marsh HC Jr, Rittershaus CW (2009) Co-administration of a CpG adjuvant (VaxImmune, CPG 7909) with CETP vaccines increased immunogenicity in rabbits and mice. Hum Vaccin 5:79-84

Tissot AC, Spohn G, Jennings GT, Shamshiev A, Kurrer MO, Windak R, Meier M, Viesti M, Hersberger M, Kundig TM, Ricci R, Bachmann MF (2013) A VLP-based vaccine against interleukin-1alpha protects mice from atherosclerosis. Eur J Immunol 43:716-722 
Tome-Carneiro J, Larrosa M, Yanez-Gascon MJ, Davalos A, Gil-Zamorano J, Gonzalvez M, Garcia-Almagro FJ, Ruiz Ros JA, Tomas-Barberan FA, Espin JC, Garcia-Conesa MT (2013) One-year supplementation with a grape extract containing resveratrol modulates inflammatory-related microRNAs and cytokines expression in peripheral blood mononuclear cells of type 2 diabetes and hypertensive patients with coronary artery disease. Pharmacol Res 72:69-82

Trajkovski M, Hausser J, Soutschek J, Bhat B, Akin A, Zavolan M, Heim MH, Stoffel M (2011) MicroRNAs 103 and 107 regulate insulin sensitivity. Nature 474:649-653

Trang P, Wiggins JF, Daige CL, Cho C, Omotola M, Brown D, Weidhaas JB, Bader AG, Slack FJ (2011) Systemic delivery of tumor suppressor microRNA mimics using a neutral lipid emulsion inhibits lung tumors in mice. Mol Ther 19:1116-1122

Truong TQ, Aubin D, Falstrault L, Brodeur MR, Brissette L (2010) SR-BI, CD36, and caveolin-1 contribute positively to cholesterol efflux in hepatic cells. Cell Biochem Funct 28:480-489

Tsukerman P, Stern-Ginossar N, Gur C, Glasner A, Nachmani D, Bauman Y, Yamin R, Vitenshtein A, Stanietsky N, Bar-Mag T, Lankry D, Mandelboim O (2012) MiR-10b downregulates the stress-induced cell surface molecule MICB, a critical ligand for cancer cell recognition by natural killer cells. Cancer Res 72:5463-5472

van Poelgeest EP, Swart RM, Betjes MG, Moerland M, Weening JJ, Tessier Y, Hodges MR, Levin AA, Burggraaf J (2013) Acute kidney injury during therapy with an antisense oligonucleotide directed against PCSK9. Am J Kidney Dis 62:796-800

van Puijvelde GH, Hauer AD, de Vos P, van den Heuvel R, van Herwijnen MJ, van der Zee R, van Eden W, van Berkel TJ, Kuiper J (2006) Induction of oral tolerance to oxidized low-density lipoprotein ameliorates atherosclerosis. Circulation 114:1968-1976

van Rooij E, Olson EN (2012) MicroRNA therapeutics for cardiovascular disease: opportunities and obstacles. Nat Rev Drug Discov 11:860-872

van Rooij E, Marshall WS, Olson EN (2008) Toward microRNA-based therapeutics for heart disease: the sense in antisense. Circ Res 103:919-928

van Rooij E, Purcell AL, Levin AA (2012) Developing microRNA therapeutics. Circ Res 110:496-507

van Wanrooij EJ, de Vos P, Bixel MG, Vestweber D, van Berkel TJ, Kuiper J (2008) Vaccination against CD99 inhibits atherogenesis in low-density lipoprotein receptor-deficient mice. Cardiovasc Res 78:590-596

Vasudevan S, Tong Y, Steitz JA (2007) Switching from repression to activation: microRNAs can up-regulate translation. Science 318:1931-1934

Veedu RN, Wengel J (2010) Locked nucleic acids: promising nucleic acid analogs for therapeutic applications. Chem Biodivers 7:536-542

Vester B, Wengel J (2004) LNA (locked nucleic acid): high-affinity targeting of complementary RNA and DNA. Biochemistry 43:13233-13241

Vickers KC, Rader DJ (2013) Nuclear receptors and microRNA-144 coordinately regulate cholesterol efflux. Circ Res 112:1529-1531

Vickers KC, Palmisano BT, Shoucri BM, Shamburek RD, Remaley AT (2011) MicroRNAs are transported in plasma and delivered to recipient cells by high-density lipoproteins. Nat Cell Biol 13:423-433

Visioli F, Davalos A (2011) Polyphenols and cardiovascular disease: a critical summary of the evidence. Mini Rev Med Chem 11:1186-1190

Visioli F, Giordano E, Nicod NM, Davalos A (2012) Molecular targets of omega 3 and conjugated linoleic fatty acids - "micromanaging" cellular response. Front Physiol 3:42

Voight BF, Peloso GM, Orho-Melander M, Frikke-Schmidt R, Barbalic M, Jensen MK, Hindy G, Holm H, Ding EL, Johnson T, Schunkert H, Samani NJ, Clarke R, Hopewell JC, Thompson JF, Li M, Thorleifsson G, Newton-Cheh C, Musunuru K, Pirruccello JP, Saleheen D, Chen L, Stewart A, Schillert A, Thorsteinsdottir U, Thorgeirsson G, Anand S, Engert JC, Morgan T, Spertus J, Stoll M, Berger K, Martinelli N, Girelli D, McKeown PP, Patterson CC, Epstein SE, Devaney J, Burnett MS, Mooser V, Ripatti S, Surakka I, Nieminen MS, Sinisalo J, Lokki ML, 
Perola M, Havulinna A, de Faire U, Gigante B, Ingelsson E, Zeller T, Wild P, de Bakker PI, Klungel OH, Maitland-van der Zee AH, Peters BJ, de Boer A, Grobbee DE, Kamphuisen PW, Deneer VH, Elbers CC, Onland-Moret NC, Hofker MH, Wijmenga C, Verschuren WM, Boer JM, van der Schouw YT, Rasheed A, Frossard P, Demissie S, Willer C, Do R, Ordovas JM, Abecasis GR, Boehnke M, Mohlke KL, Daly MJ, Guiducci C, Burtt NP, Surti A, Gonzalez E, Purcell S, Gabriel S, Marrugat J, Peden J, Erdmann J, Diemert P, Willenborg C, Konig IR, Fischer M, Hengstenberg C, Ziegler A, Buysschaert I, Lambrechts D, Van de Werf F, Fox KA, El Mokhtari NE, Rubin D, Schrezenmeir J, Schreiber S, Schafer A, Danesh J, Blankenberg S, Roberts R, McPherson R, Watkins H, Hall AS, Overvad K, Rimm E, Boerwinkle E, TybjaergHansen A, Cupples LA, Reilly MP, Melander O, Mannucci PM, Ardissino D, Siscovick D, Elosua R, Stefansson K, O’Donnell CJ, Salomaa V, Rader DJ, Peltonen L, Schwartz SM, Altshuler D, Kathiresan S (2012) Plasma HDL cholesterol and risk of myocardial infarction: a mendelian randomisation study. Lancet 380:572-580

Wang D, Xia M, Yan X, Li D, Wang L, Xu Y, Jin T, Ling W (2012) Gut microbiota metabolism of anthocyanin promotes reverse cholesterol transport in mice via repressing miRNA-10b. Circ Res 111:967-981

Wang L, Jia XJ, Jiang HJ, Du Y, Yang F, Si SY, Hong B (2013) MicroRNAs 185, 96, and 223 repress selective high-density lipoprotein cholesterol uptake through posttranscriptional inhibition. Mol Cell Biol 33:1956-1964

Wiggins JF, Ruffino L, Kelnar K, Omotola M, Patrawala L, Brown D, Bader AG (2010) Development of a lung cancer therapeutic based on the tumor suppressor microRNA-34. Cancer Res 70:5923-5930

Wigren M, Kolbus D, Duner P, Ljungcrantz I, Soderberg I, Bjorkbacka H, Fredrikson GN, Nilsson $\mathrm{J}$ (2011) Evidence for a role of regulatory T cells in mediating the atheroprotective effect of apolipoprotein B peptide vaccine. J Intern Med 269:546-556

Xu Q, Dietrich H, Steiner HJ, Gown AM, Schoel B, Mikuz G, Kaufmann SH, Wick G (1992) Induction of arteriosclerosis in normocholesterolemic rabbits by immunization with heat shock protein 65. Arterioscler Thromb 12:789-799

Xu J, Wang Y, Tan X, Jing H (2012) MicroRNAs in autophagy and their emerging roles in crosstalk with apoptosis. Autophagy 8:873-882

Yasuda T, Ishida T, Rader DJ (2010) Update on the role of endothelial lipase in high-density lipoprotein metabolism, reverse cholesterol transport, and atherosclerosis. Circ J 74:2263-2270

Yoo BH, Bochkareva E, Bochkarev A, Mou TC, Gray DM (2004) 2'-O-methyl-modified phosphorothioate antisense oligonucleotides have reduced non-specific effects in vitro. Nucleic Acids Res 32:2008-2016

Yu RZ, Geary RS, Monteith DK, Matson J, Truong L, Fitchett J, Levin AA (2004) Tissue disposition of $2^{\prime}-\mathrm{O}-(2-$ methoxy) ethyl modified antisense oligonucleotides in monkeys. J Pharm Sci 93:48-59

Zamecnik PC, Stephenson ML (1978) Inhibition of Rous sarcoma virus replication and cell transformation by a specific oligodeoxynucleotide. Proc Natl Acad Sci USA 75:280-284

Zatsepin TS, Oretskaya TS (2004) Synthesis and applications of oligonucleotide-carbohydrate conjugates. Chem Biodivers 1:1401-1417

Zhang DW, Lagace TA, Garuti R, Zhao Z, McDonald M, Horton JD, Cohen JC, Hobbs HH (2007) Binding of proprotein convertase subtilisin/kexin type 9 to epidermal growth factor-like repeat A of low density lipoprotein receptor decreases receptor recycling and increases degradation. J Biol Chem 282:18602-18612

Zhang J, Kelley KL, Marshall SM, Davis MA, Wilson MD, Sawyer JK, Farese RV Jr, Brown JM, Rudel LL (2012a) Tissue-specific knockouts of ACAT2 reveal that intestinal depletion is sufficient to prevent diet-induced cholesterol accumulation in the liver and blood. J Lipid Res 53:1144-1152

Zhang J, Yu Y, Nakamura K, Koike T, Waqar AB, Zhang X, Liu E, Nishijima K, Kitajima S, Shiomi M, Qi Z, Yu J, Graham MJ, Crooke RM, Ishida T, Hirata K, Hurt-Camejo E, Chen YE, 
Fan J (2012b) Endothelial lipase mediates HDL levels in normal and hyperlipidemic rabbits. J Atheroscler Thromb 19:213-226

Zhang L, McCabe T, Condra JH, Ni YG, Peterson LB, Wang W, Strack AM, Wang F, Pandit S, Hammond H, Wood D, Lewis D, Rosa R, Mendoza V, Cumiskey AM, Johns DG, Hansen BC, Shen X, Geoghagen N, Jensen K, Zhu L, Wietecha K, Wisniewski D, Huang L, Zhao JZ, Ernst R, Hampton R, Haytko P, Ansbro F, Chilewski S, Chin J, Mitnaul LJ, Pellacani A, Sparrow CP, An Z, Strohl W, Hubbard B, Plump AS, Blom D, Sitlani A (2012c) An antiPCSK9 antibody reduces LDL-cholesterol on top of a statin and suppresses hepatocyte SREBP-regulated genes. Int J Biol Sci 8:310-327

Zhang Y, Xiong Q, Hu X, Sun Y, Tan X, Zhang H, Lu Y, Liu J (2012d) A novel atherogenic epitope from Mycobacterium tuberculosis heat shock protein 65 enhances atherosclerosis in rabbit and LDL receptor-deficient mice. Heart Vessel 27:411-418

Zhang LY, Ho-Fun Lee V, Wong AM, Kwong DL, Zhu YH, Dong SS, Kong KL, Chen J, Tsao SW, Guan XY, Fu L (2013) MicroRNA-144 promotes cell proliferation, migration and invasion in nasopharyngeal carcinoma through repression of PTEN. Carcinogenesis 34:454-463

Zhou X, Caligiuri G, Hamsten A, Lefvert AK, Hansson GK (2001) LDL immunization induces Tcell-dependent antibody formation and protection against atherosclerosis. Arterioscler Thromb Vasc Biol 21:108-114

Zincarelli C, Soltys S, Rengo G, Rabinowitz JE (2008) Analysis of AAV serotypes 1-9 mediated gene expression and tropism in mice after systemic injection. Mol Ther 16:1073-1080 